\title{
Identification of TACC1, NOV, and PTTG1 as new candidate genes associated with endocrine therapy resistance in breast cancer
}

\author{
Sandra E Ghayad ${ }^{1,2,3,4 *}$, Julie A Vendrell ${ }^{1,2,3,4 *}$, Ivan Bieche $^{5}$, Frédérique Spyratos ${ }^{5}$, \\ Charles Dumontet $^{1,3,6}$, Isabelle Treilleux ${ }^{4}$, Rosette Lidereau ${ }^{5}$ and Pascale A Cohen ${ }^{1,2,3,4}$ \\ ${ }^{1}$ Université de Lyon, 69008 Lyon, France, \\ ${ }^{2}$ Université Lyon 1, ISPB, Faculté de Pharmacie de Lyon, 69008 Lyon, France, \\ ${ }^{3}$ INSERM, U590, 69008 Lyon, France, \\ ${ }^{4}$ Centre Léon Bérard, FNCLCC, 69008 Lyon, France, \\ ${ }^{5}$ Laboratoire d'Oncogénétique, INSERM U735, 92210 St-Cloud, France \\ ${ }^{6}$ Université Lyon 1, Faculté de Médecine, 69008 Lyon, France \\ (Correspondence should be addressed to P A Cohen; Email: pascale.cohen@recherche.univ-lyon1.fr) \\ *(S E Ghayad and J A Vendrell contributed equally to this work)
}

\begin{abstract}
Cross-resistance to molecules used in endocrine therapy is among the main challenges in the treatment of estrogen receptor- $\alpha(E R \alpha)$ positive breast cancer. In this study, we used two different cell models of resistance to anti-estrogens: MVLN/CL6.7 cells and VP229/VP267 cells selected after exposure to tamoxifen respectively in vitro and in vivo to characterize a phenotype rarely observed, i.e. acquisition of cross-resistance to the pure ER antagonist fulvestrant. As MVLN/CL6.7 cells and VP229/VP267 cell lines are original and valuable models of cross-resistance to tamoxifen and fulvestrant, we examined candidate genes using a RTQ-PCR strategy to identify new biomarkers of endocrine resistance. Out of the 26 candidate genes tested, 19 displayed deregulation of expression at the basal level in at least one of the two resistant cell lines. Eight genes (TACC1, NOV, PTTG1, MAD2L1, BAK1, TGFB2, BIRC5, and CCNE2) were significantly overexpressed in samples from ER-positive breast cancer patients who relapsed after tamoxifen treatment $(n=24)$ compared with samples from patients who did not $(n=24)$. Five genes (TACC1, NOV, PTTG1, BAK1, and TGFB2) were correlated with significantly shorter relapse-free survival (univariate analysis). Finally, we identified TACC1 and a three-gene expression signature (TACC1, NOV, and PTTG1) as independent prognostic markers (multivariate analysis). Aberrant mRNA and protein levels of TACC1, NOV, and PTTG1 were also observed under tamoxifen and/or fulvestrant exposure in resistant CL6.7 cells compared with their respective control MVLN cells. In conclusion, our data identify TACC1, NOV, and PTTG1 as promising new markers that could be used in the clinical management of ER-positive breast cancer patients.
\end{abstract}

Journal of Molecular Endocrinology (2009) 42, 87-103

\section{Introduction}

Breast carcinoma, the most common female cancer, is currently undergoing an alarming increase. Breast cancer growth is regulated by estrogen, which acts by binding to the estrogen receptor $\alpha(\mathrm{ER} \alpha) . \mathrm{ER} \alpha$ is routinely used as a prognostic and predictive marker in the management of breast cancer patients, in particular to identify patients who may respond to endocrine therapy. The selective estrogen receptor modulator tamoxifen (Tam) which aims to block the $\mathrm{ER} \alpha$ has been the mainstay of hormonal therapy in both early and advanced breast cancer patients for approximately three decades (EBCTC Group 1998, Gradishar 2005). However, Tam is only partially effective because of intrinsic or acquired tumor resistance. Approximately, $40 \%$ of patients with
ER-positive breast cancer will not respond to Tam (de novo resistance). Moreover, long-term follow-up and clinical trials have demonstrated that up to $62 \%$ of cancers initially responsive to endocrine therapy subsequently escape control with the patient requiring salvage surgery (Horobin et al. 1991, Fennessy et al. 2004). In general, Tam-resistant tumors respond to second-line endocrine therapy, suggesting that resistance is not attributable to the loss of or alterations in $\mathrm{ER} \alpha$, and that tumor growth may involve functional ER $\alpha$ signaling (Howell et al. 1995, Osborne 1998). New endocrine therapies have recently emerged, in particular with the selective estrogen receptor downregulator (SERD) fulvestrant (ICI 182,780). The mechanism of action of this ER antagonist is different from that of Tam, as binding of fulvestrant to ER induces destabilization and degradation of the 
receptor. Moreover, Tam only blocks the transcriptional activating function AF2 of ER, and thus only partially inactivates ER-regulated transcription (Tzukerman et al. 1994, McDonnell et al. 1995), while fulvestrant blocks both AF1 and AF2 functions of ER, resulting in complete abrogation of the transcription of ER-regulated genes (Wakeling et al. 1991, Dowsett et al. 2005). Two phase III trials have demonstrated that fulvestrant is as efficient as anastrozole, a thirdgeneration aromatase inhibitor, in second-line treatment for postmenopausal women with advanced-stage Tam-resistant breast cancer (Dodwell \& Pippen 2006). Recent clinical trials have also shown that in patients with advanced breast cancer progressing on prior endocrine therapy with Tam or an aromatase inhibitor, fulvestrant produces a clinical benefit in respectively $43 \%$ and $30 \%$ of the patients (Howell et al. 2002, Osborne et al. 2002, Perey et al. 2007). These clinical data underline not only the importance of fulvestrant in the therapeutic arsenal against ER+ breast cancers, but also suggest that in a subset of patients who have developed resistance to first-line endocrine therapy (with Tam or aromatase inhibitors), cross-resistance to fulvestrant can also occur.

In in vitro-established resistant breast cancer cells, Tam-resistant cells selected under Tam exposure are usually sensitive to fulvestrant (Parisot et al. 1999, Kilker et al. 2004, Martin et al. 2005, Shaw et al. 2006), whereas resistant cell lines established under fulvestrant selection are commonly cross-resistant to Tam (Lykkesfeldt et al. 1995, Brunner et al. 1997, Fan et al. 2006a, Shaw et al. 2006). Few studies have reported a decreased sensitivity of Tam-resistant breast cancer cells or xenografts to fulvestrant (Lykkesfeldt et al. 1994, Naundorf et al. 2000), but none, to our knowledge, has demonstrated the total abrogation of fulvestrant response. In this study, we fully characterized for the first time the endocrine resistance developed by two cellular models of acquired Tam resistance: in vitroselected Tam-resistant CL6.7 cells (Badia et al. 2000) and in vivo-selected Tam-resistant VP267 cells (McCallum \& Lowther 1996). Strikingly, we found that, while selected under Tam exposure, CL6.7 and VP267 cells also acquired cross-resistance to fulvestrant, characterized by a total abrogation of the SERD's response. Thus, the combination of CL6.7 and VP267 cells represents a good cellular model for the genomic screening of molecular markers of endocrine resistance with potential clinical relevance. The recent development of effective tools for investigating gene-expression profiles has already led to the identification of new diagnostic and prognostic markers. These tools include cDNA arrays (van 't Veer et al. 2002, van de Vijver $e t$ al. 2002, Ma et al. 2004, Frasor et al. 2006) and real-time quantitative RT-PCR (RTQ-PCR). While cDNA array allows the screening of a large number of genes at a time, RTQ-PCR is an alternative approach that has already proved useful for the identification of molecular markers. Indeed, RTQ-PCR is an accurate, sensitive and reproducible technique more suitable for detecting small variations in gene expression and weakly expressed genes (Bieche et al. 2004). While this technique allows the quantitative measurement of only a small number of selected candidate genes, it has already been successfully used in several studies aimed at identifying markers associated with endocrine therapy resistance (Bieche et al. 2004, Paik et al. 2004, Tozlu et al. 2006).

In two previous genomic studies, we had identified by cDNA arrays new genes demonstrated as estrogenmodulated or associated with agonist activity of 4-hydroxy-tamoxifen (OH-Tam) and hyper-response to $17 \beta$-estradiol $\left(\mathrm{E}_{2}\right)$ in $\mathrm{OH}-\mathrm{Tam}$-resistant breast cancer cell lines (Vendrell et al. 2004, 2005). With the aim to identify gene expression deregulation associated with resistance to Tam and fulvestrant, we selected from these studies 26 candidate genes whose biological functions are associated with cell proliferation, transformation, apoptosis, DNA repair, and DNA replication. We analyzed by RTQ-PCR the expression of the 26 candidate genes in CL6.7 and VP267 cells. Genes with a deregulated expression in resistant cells were then selected to be explored in a series of 48 ER + breast tumor samples from postmenopausal patients, who relapsed after primary surgery and adjuvant endocrine therapy $(n=24)$ or did not $(n=24)$.

\section{Materials and methods}

\section{Cell-proliferation analysis}

MVLN, CL6.7, CL6.8, VP229, and VP267 cells were grown as described previously (Demirpence et al. 1993, McCallum \& Lowther 1996), then purged for 4 days in DMEM without Phenol Red and supplemented with $3 \%$ steroid-depleted, dextran-coated, charcoal-treated FCS (DCC medium). The cells were then treated (with media changed every two days) in the absence or the presence of $\mathrm{E}_{2}$ (Sigma, Saint Louis, MO, USA), OH-Tam (Sigma) or fulvestrant (Tocris, Ellisville, MO, USA). Proliferating cells were analyzed using the cell proliferation ELISA, 5-bromodeoxyuridine (BrdU) colorimetric kit (Roche) as previously described (Vendrell et al. 2005).

\section{Western blot}

Cell extract preparation and western blot analysis were performed as previously described (Vendrell et al. 2004). ER $\alpha$ and NOV antibodies were purchased from Santa Cruz Biotechnology (Santa Cruz, CA, USA), 
TACC1 antibody from Upstate (Lake Placid, NY, USA), PTTG1 antibody from Zymed Laboratories (San Francisco, CA, USA) and $\alpha$-tubulin antibody from Sigma.

\section{Breast tumor samples}

Samples from primary breast tumors were obtained from women operated on at the Centre René Huguenin (St Cloud, France) between 1980 and 1994. Informed consent was obtained from all patients and the study was approved by the ethics committee of the institution. A set of $48 \mathrm{ER}+$ breast tumor samples was used in this study; the tumors were taken from patients treated with primary surgery followed by adjuvant Tam alone: thirty-nine $(81 \cdot 2 \%)$ underwent a mastectomy and nine (18.8\%) had breast-conserving surgery. Twenty-four patients relapsed under Tam treatment and developed metastases ('Relapse' group) and 24 patients did not ('No relapse' group). Standard prognostic factors are shown in Table 1. The patients (mean age: $70 \cdot 7$ years; range: $54-86$ ) met the following criteria: primary unilateral postmenopausal breast carcinoma; complete clinical, histological, and biological information available; no radiotherapy or chemotherapy before surgery; and full follow-up at the Centre René Huguenin. The histological type and the number of positive axillary nodes were established at the time of surgery. The malignancy of infiltrating carcinomas was scored according to the histological grading system of Bloom \& Richardson (1957) and Elston \& Ellis (1993). At the time of surgery (years 1980-1994), $\mathrm{ER} \alpha$ status was determined at the protein level by using quantitative biochemical methods: dextran-coated charcoal method until 1988 and enzymatic immunoassay

Table 1 Characteristics of the $48 \mathrm{ER}+$ tumors taken from patients treated with primary surgery followed by adjuvant Tam alone, and who relapsed or did not

\begin{tabular}{|c|c|c|c|}
\hline & & RFS $^{a}$ & \\
\hline & $\begin{array}{l}\text { Number of } \\
\text { patients }\end{array}$ & $\begin{array}{l}\text { Number of } \\
\text { events (\%) }\end{array}$ & $P^{\mathrm{b}}$ \\
\hline Age & & & \\
\hline$\leq 70$ & 27 & $14(51 \cdot 9)$ & NS \\
\hline$>70$ & 21 & $10(47 \cdot 6)$ & $(0.39)$ \\
\hline SBR histological grade ${ }^{c}$ & & & \\
\hline $\mathrm{I}+\mathrm{II}$ & 38 & $16(42 \cdot 1)$ & NS \\
\hline III & 10 & $8(80.0)$ & $(0 \cdot 13)$ \\
\hline Lymph node status & & & \\
\hline$\leq 3$ & 32 & $13(40 \cdot 6)$ & 0.023 \\
\hline$>3$ & 16 & $11(68 \cdot 7)$ & \\
\hline Macroscopic tumor size (mm) & & & \\
\hline$\leq 30$ & 32 & $14(43 \cdot 8)$ & \\
\hline$>30$ & 16 & $10(62 \cdot 5)$ & $(0 \cdot 076)$ \\
\hline
\end{tabular}

NS, not significant.

${ }^{a}$ RFS, relapse-free survival. Local and/or regional recurrences, and/or metastases.

${ }^{\mathrm{b}}$ Log-rank test.

${ }^{c}$ Scarff-Bloom-Richardson classification. thereafter. We have recently confirmed the ER $\alpha$ status of these 48 tumors by RTQ-PCR. The patients had physical examinations and routine chest radiography every 3 months for 2 years, then annually. Mammograms were performed annually. The median follow-up was $7 \cdot 2$ years (range $1 \cdot 5-10 \cdot 0$ years). All the patients received postoperative adjuvant endocrine therapy (Tam, $20 \mathrm{mg}$ daily for 3-5 years), and no other treatment. Patients in the 'Relapse' group experienced metastases between 1.3 and $10 \cdot 0$ years after surgery and the beginning of Tam treatment. Tumor samples containing more than $70 \%$ of tumor cells were considered suitable for the study. Immediately following surgery, the tumor samples were placed in liquid nitrogen until RNA extraction. Specimens of adjacent normal breast tissue from three breast cancer patients and normal breast tissue from three women undergoing cosmetic breast surgery were used as sources of normal RNA.

\section{RTQ-PCR analysis}

Total RNA was extracted by cesium chloride ultracentrifugation, and RNA integrity was checked using the BioAnalyzer 2100 (Agilent Technologies, Palo Alto, CA, USA). One microgram of total RNA from each sample was reverse transcribed, and RTQ-PCR measurements were performed as described previously (Girault et al. 2003, Vendrell et al. 2005) using a LightCycler (Roche) or an ABI Prism 7700 Sequence Detection System (Perkin-Elmer Applied Biosystems, Foster City, CA, USA) with the corresponding SYBR Green Kit, according to the manufacturer's recommendations. For each gene, mRNA levels in the breast samples were normalized such that the median value of six normal human breast tissue samples was 1 .

\section{Statistical analyses}

Gene-expression levels in subgroups of breast tumor samples were compared using the Kruskal-Wallis test. Differences between groups were judged significant at a confidence level greater than $95 \%(P<0 \cdot 05)$. To visualize the capacity of a molecular marker to discriminate between two populations (in the absence of an arbitrary cut-off value), we summarized the data in a receiver operating characteristic (ROC) curve (Hanley \& McNeil 1982). ROC curves plot sensitivity (true positives) on the $y$-axis against one specificity (false positives) on the $x$-axis, considering each value as a possible cut-off. The area under curve (AUC) was calculated and used as a single measure of the discriminatory capacity of each molecular marker. When a molecular marker has no discriminative value, the ROC curve lies close to the diagonal and the AUC is close to $0 \cdot 5$. Conversely, when a marker has strong discriminative value, the ROC curve comes closest to the 
upper left-hand corner (or to the lower right-hand corner) and the AUC is close to $1 \cdot 0$ (or 0 ). Hierarchical clustering was performed using the GenANOVA software (Didier et al. 2002). Relapse-free survival (RFS) was defined as the interval between diagnosis and detection of the first relapse (local and/or regional recurrence, and/or distant metastasis). Survival distributions were estimated by the Kaplan-Meier method (Kaplan \& Meier 1958) and the significance of differences between survival rates was ascertained by using the log-rank test (Peto et al. 1977). Cox's proportional hazards regression model (Cox 1972) was used to assess prognostic significance.

\section{Immunohistochemical and RTQ-PCR analyses of breast tumor samples}

Ten ER + frozen breast tumors from patients diagnosed at Centre Léon Bérard were obtained from the Biological Resource Centre of Centre Léon Bérard, (French agreement number: DC-2008-99) after approval by the institutional review board and ethics committee, with fully informed patient consent. Paraffin-embedded breast tumors were fixed in $10 \%$ formalin and inserted in tissue microarray blocks. The blocks containing invasive carcinoma were sectioned at a thickness of $4 \mu \mathrm{m}$. After deparaffinization and rehydration, endogenous peroxidases were blocked by incubating the slides in $5 \%$ hydrogen peroxide in sterile water. The slides were then incubated with a protein blocking agent (Immunotech, Marseille, France) for $10 \mathrm{~min}$ at room temperature. For heat-induced antigen retrieval, tissue sections were boiled using a water bath at $97^{\circ} \mathrm{C}$ for 50 min either in $10 \mathrm{mM}$ high pH buffer (Dako, Trappes, France) for anti-NOV antibody or in citrate buffer (Dako) for anti-PTTG1 antibody. The slides were then incubated at room temperature for $30 \mathrm{~min}$ with the anti-NOV goat polyclonal antibody (Santa Cruz) or for $1 \mathrm{~h}$ with the antiPTTG1 polyclonal rabbit antibody (Zymed). Both antibodies were diluted using an antibody diluent solution (Dako) at 1/800 (anti-NOV antibody) or at 1/600 (anti-PTTG1 antibody). After rinsing in PBS, the slides were incubated with a biotinylated secondary antibody bound to a streptavidin-peroxidase conjugate $(\mathrm{LSAB}+\mathrm{Kit}, \mathrm{Dako})$. Bound antibody was revealed by adding 3,3-diaminobenzidine. Sections were counterstained with hematoxylin. The slides were analyzed independently by the pathologist and the technician who assessed both the percentage of stained cells and the staining intensity $(0=$ none, $1+=$ low, $2+=$ intermediate, $3+=$ high) in infiltrative carcinomatous cells. The tumors were then stratified according to a score established by multiplying the percentage of stained cells by the intensity. The cut-off values chosen to classify the tumors into the 'low protein expression' group or the 'high protein expression' group were determined after a pre-observation performed on a larger set of breast tumors ( $n=80$, data not shown). As three levels of intensity could be observed for NOV immunostaining and only two for PTTG1 immunostaining, the staining score had to be at least 100 for NOV and at least 40 for PTTG1 to belong to the 'high protein expression' group.

The same 10 breast tumor samples were disrupted using the TissueLyser (Qiagen) and total RNA was extracted using the RNeasy Mini Kit (Qiagen) according to the manufacturer's recommendations. Total RNA was subsequently quantified on a Nanodrop ND1000 spectrophotometer (Nanodrop Technologies, Wilmington, DE, USA), and RNA integrity was checked using the BioAnalyzer 2100 (Agilent Technologies). RTQ-PCR for NOV and PTTG1 was performed as described above. For each gene, the $10 \mathrm{ER}+$ breast tumors were divided into two groups: samples with 'low mRNA expression level' (lower than the median mRNA level) and those with 'high mRNA expression level' (higher than the median mRNA level).

\section{Results}

\section{The CL6.7 cell line developed a phenotype of OH-Tam resistance similar to that of the previously charac- terized CL6.8 cells}

MVLN is an ER+, hormone-responsive, and OH-Tamsensitive breast carcinoma cell line derived from MCF-7 cells (Demirpence et al. 1993). Six-month exposure of MVLN cells to OH-Tam allowed the emergence of several OH-Tam-resistant (OTR) but still estrogendependent cellular clones (Badia et al. 2000). We have previously fully characterized the phenotype of OTR CL6.8 cells, defined by an agonist activity of OH-Tam and hypersensitivity to $\mathrm{E}_{2}$ (Vendrell et al. 2005). The OTR CL6.7 cell line remains to be characterized.

One of the mechanisms possibly involved in endocrine therapy resistance is an alteration in the expression of ER $\alpha$ and/or ER $\beta$ (Johnston et al. 1995, Speirs et al. 1999). We found that, as previously observed for OTR CL6.8 cells (Vendrell et al. 2005), ER $\alpha$ protein expression was decreased in OTR CL6.7 cells when compared with MVLN cells, and this decrease was more pronounced in CL6.7 than in CL6.8 cells (Fig. 1A). Investigation of $E S R 1 / E R \alpha$ mRNA levels by RTQ-PCR (Table 2) demonstrated no difference in the ESRI/ER $\alpha$ gene expression level between CL6.7 and MVLN cells $(-1 \cdot 2$-fold), suggesting that the down-regulation of $\mathrm{ER} \alpha$ expression in CL6.7 cells mainly occurs at a posttranscriptional level. On the contrary, ESR1/ER $\alpha$ gene expression was decreased in the CL6.8 cell line when compared with MVLN ( $-2 \cdot 4$-fold, data not shown). $E S R 2 / E R \beta$ mRNA level was 1000-fold lower than ESR1/ $E R \alpha$ mRNA and no difference in expression was observed, either between OTR CL6.7 and MVLN cells 
A

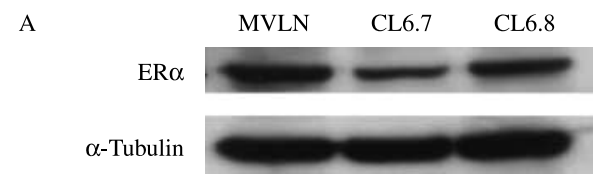

B
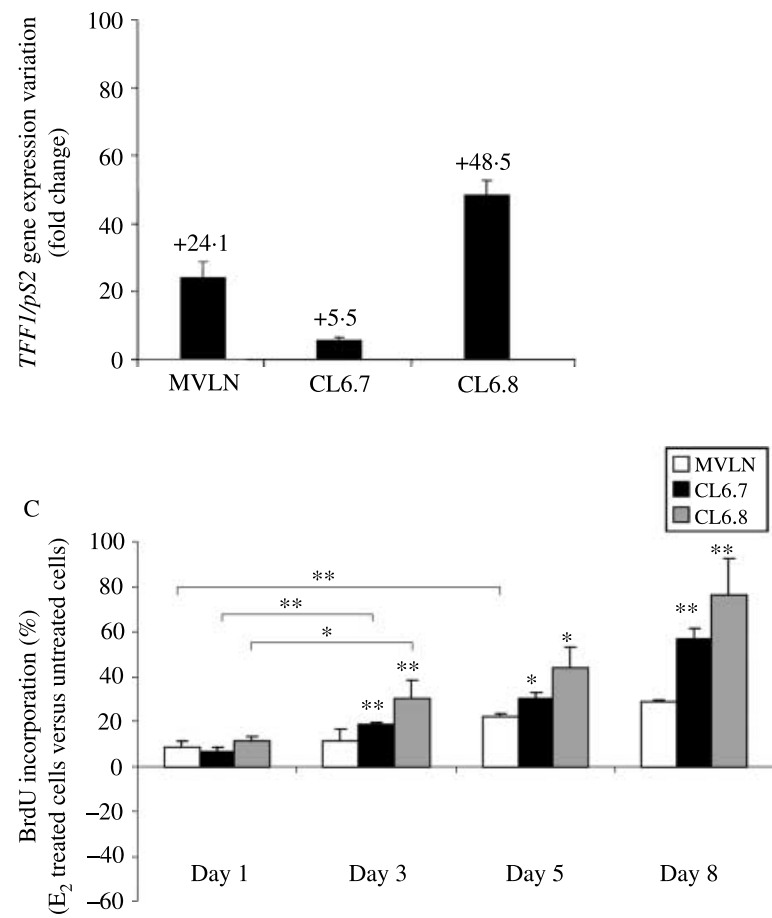

Figure $1 \mathrm{ER} \alpha$ expression and functionality in CL6.7 cells. (A) Exploration of $E R \alpha$ protein expression at the basal level in MVLN, CL6.7, and CL6.8 cells by western blot as described in the Materials and methods section using anti-ER $\alpha$ antibody. Expression of $\alpha$-tubulin was used as invariant control. (B) TFF1 (pS2) gene expression variations (fold change) measured by RTQ-PCR in MVLN, CL6.7, and CL6.8 cells after 4 days of $E_{2}$ treatment. (C) Proliferative response of MVLN (white bars), CL6.7 (black bars), and CL6.8 (grey bars) cells grown in DCC medium, then treated for $1,3,5$, or 8 days with vehicle or $1 \mathrm{nM} \mathrm{E}_{2}$. Results are expressed as a percentage of cells incorporating BrdU in the presence of treatment compared with untreated cells. Results are expressed as means \pm s.D. from three independent experiments. ${ }^{*} P<0.05$ and ${ }^{* *} P<0.01$ versus the corresponding MVLN treatment according to Student's $t$-test.

(Table 2) or between OTR CL6.8 and MVLN cells (data not shown). The functionality of the ESR1/ER $\alpha$ gene and the basal transcription machinery previously documented for CL6.8 cells (Vendrell et al. 2005) were also demonstrated in the present study for CL6.7 cells, based on several findings: i) $96 \mathrm{~h}$ exposure to $\mathrm{E}_{2}$ $(1 \mathrm{nM})$ is capable of inducing increased $(+5 \cdot 5$-fold $)$ TFF1 ( $p$ S2) mRNA levels (Fig. 1B); ii) $24 \mathrm{~h}$ exposure to $\mathrm{E}_{2}(1 \mathrm{nM})$ stimulates luciferase activity $(+10$-fold $)$ in ERE-luciferase reporter plasmid-transfected CL6.7 cells (data not shown); iii) in a cell proliferation assay measured by BrdU labeling (Fig. 1C), $\mathrm{E}_{2}$ is capable of stimulating CL6.7 cell proliferation. The phenotype developed by the CL6.7 cell line also exhibits a hyperresponse to $\mathrm{E}_{2}$ evidenced by the earlier detection of $\mathrm{E}_{2}$ stimulation in CL6.7 cells (day 3) than in the MVLN cell line (day 5 ), and by a significantly greater amplitude of proliferation under $\mathrm{E}_{2}$ treatment in OTR cells than in MVLN cells (Fig. 1C), similarly to what was previously observed for CL6.8 cells (Fig. 1C and Vendrell et al. 2005). The phenotype of OH-Tam resistance developed by CL6.7 cells was characterized under OH-Tam exposure by the loss of the cytostatic activity of the molecule that is detectable in MVLN cells and the occurrence of a strong stimulation of CL6.7 cell proliferation (estrogen-like effect; Fig. 2A). This phenotype was very close to the one developed by OTR CL6.8 cells (Fig. 2A and Vendrell et al. 2005). Taken together, these observations indicate that the OTR CL6.7 and CL6.8 cellular clones obtained from MVLN cells using the same selection process (6-month $200 \mathrm{nM}$ OH-Tam treatment) developed a similar resistance phenotype defined by agonist activity of $\mathrm{OH}$-Tam and hypersensitivity to $\mathrm{E}_{2}$.

\section{OTR CL6.7 cells, but not OTR CL6.8 cells, developed cross-resistance to fulvestrant}

As fulvestrant may be used as second-line therapy following Tam resistance, we investigated the proliferation response of MVLN, CL6.7, and CL6.8 cells under $100 \mathrm{nM}$ fulvestrant exposure for $1,3,5$, and 8 days (Fig. 2B). Fulvestrant treatment completely abolished the proliferation of MVLN cells detectable from the third day of treatment. Fulvestrant was also able to inhibit the proliferation of the CL6.8 cell line in a time-dependent manner, but with different kinetics. Indeed, after 3 and 5 days of treatment, CL6.8 cells were significantly less sensitive to the inhibition of cell proliferation induced by fulvestrant than MVLN cells $(P<0 \cdot 01)$, but after 8 days of treatment the inhibitory action of the drug was similar in both cell lines (Fig. 2B). More surprisingly, CL6.7 cells developed total resistance to the compound, as no cytostatic activity of fulvestrant could be observed after any exposure time. The patterns of cell growth observed after exposure to both $\mathrm{E}_{2}$ and fulvestrant for 5 days were identical to those obtained on fulvestrant alone (Fig. 2C), suggesting that in CL6.7 cells, fulvestrant is still able to prevent the $\mathrm{E}_{2}$ stimulation of cell proliferation, but is unable to exert its cytostatic activity. As fulvestrant is known to bind to $\mathrm{ER} \alpha$ and to induce the degradation of the receptor via the proteasome (Dauvois et al. 1992, Fan et al. 2003), the loss of fulvestrant-induced ER $\alpha$ degradation in CL6.7 cells would be an obvious explanation for the development of resistance to this molecule. As shown in Fig. 2D, fulvestrant treatment is able to induce a decrease in $\mathrm{ER} \alpha$ protein expression in MVLN and CL6.8 cells, as expected, but also in the fulvestrant-resistant CL6.7 cell line. This suggests that 
Table 2 Genes differentially expressed at the basal level in the CL6.7 cell line compared with the MVLN cell line, and in the VP267 compared with the VP229 cells

\begin{tabular}{lll} 
Symbol & FC \\
\hline
\end{tabular}

\section{Gene name}

Estrogen receptors

Estrogen receptor $1(\mathrm{ER} \alpha)$

Estrogen receptor 2 (ER $\beta)$

ESR1
ESR2
CCNA2*
CCNB2
CCNE2
CDKN1A
EGR2
GADD45A
IRS1
MAD2L1*
MYBL2
NOV
TACC1

$-1 \cdot 2$

$-1 \cdot 6$

$-2 \cdot 9$

Cell proliferation

Cyclin A2

Cyclin B2

Cyclin E2

Cyclin-dependent kinase inhibitor 1A (p21, Cip1)

Early growth response 2

Growth arrest and DNA-damage-inducible, alpha

Insulin receptor substrate 1

MAD2 mitotic arrest deficient-like 1

v-myb myeloblastosis viral oncogene homolog (avian)-like 2

Nephroblastoma overexpressed gene

Transforming, acidic coiled-coil

Transformation

Pituitary tumor-transforming 1

PTTG1*

$1 \cdot 2$

4.2

$-2 \cdot 2$

$1 \cdot 5$

$-2 \cdot 3$

2.0

$2 \cdot 4$

$-2.5$

$-1 \cdot 2$

3.7

$2 \cdot 8$

$-1 \cdot 4$

Apoptosis

BCL2-antagonist/killer 1

BCL2 binding component 3

BCL2-interacting killer

Baculoviral IAP repeat-containing 5

Death associated protein 3

Transforming growth factor, $\beta 1$

Transforming growth factor, $\beta 2$

Transforming growth factor, $\beta$ receptor II (70/80kDa)

Tumor necrosis factor

Tumor necrosis factor receptor 1-associated death domain protein

DNA repair and DNA replication

Breast cancer, type 2

Hypoxanthine guanine phosphoribosyltransferase 1

RAD51 homolog

Topoisomerase (DNA) II $\propto 170 \mathrm{kDa}$

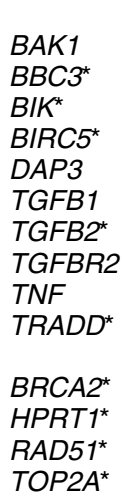

$1 \cdot 2$

2:0

$-1 \cdot 1$

$-1 \cdot 3$

$-2 \cdot 8$

2.6

$-1 \cdot 4$

$-2 \cdot 0$

3.4

$2 \cdot 4$

1.9

$1 \cdot 4$

$1 \cdot 3$

$-1 \cdot 9$

$1 \cdot 1$
$1 \cdot 2$

2. 6

$-5.0$

$-1.5$

$-7.2$

4. 4

9.2

$-1 \cdot 2$

$-2 \cdot 6$

$-1 \cdot 6$

$-1.8$

$2 \cdot 9$

$1 \cdot 7$

$-1 \cdot 3$

4.6

$-1.4$

2.2

1.6

$-5.0$

$-1.5$

3.5

$1 \cdot 1$

$-1 \cdot 6$

$-1.6$

$-2 \cdot 2$

2.5

The expression values presented are expressed in terms of fold change (FC) values (calculated by dividing the resistant cell line gene-expression value by the one obtained for the corresponding sensitive cell line) and represent means from at least two independent RTQ-PCR measurements. Gene-expression variation was considered significant for $\mathrm{FC} \geq 2$ or $\mathrm{FC} \leq-2$. Upregulations and down-regulations are indicated in bold. Asterisks represent genes on which an estrogen-like gene expression signature under $\mathrm{OH}-\mathrm{Tam}$ treatment was previously demonstrated by Vendrell et al. (2005).

other unknown mechanisms are involved in the development of resistance to this SERD by CL6.7 cells.

\section{In vivo-selected VP cell lines are another breast cancer cell model of cross-resistance to Tam and to fulvestrant}

The VP229 cell line was established from a primary breast tumor removed before any pharmacological treatment, whereas VP267 was derived from the same patient after a local recurrence following Tam treatment (McCallum \& Lowther 1996). These cells represent another interesting cellular model because they were selected in vivo under Tam treatment, but they are still not fully characterized. We explored ER $\alpha$ expression in the two VP cell lines, and we found a down-regulation in VP267 cells compared with VP229 cells, both at the mRNA level $(-2 \cdot 9$-fold, Table 2$)$ and at the protein level (Fig. 3A). ESR2/ERß mRNA levels were 1000-fold lower than ESR1/ER $\alpha$ mRNA levels and no difference in expression was noted between VP229 and VP267 cells (Table 2). The functionality of ER $\alpha$ was shown by the induction of TFF1 ( $p S 2$ ) gene expression under $\mathrm{E}_{2}$ stimulation in VP229 and VP267 cell lines $(+49 \cdot 1$-fold and $+13 \cdot 1$-fold respectively, Fig. 3B). ER-driven transcriptional activity was assessed by a gene reporter assay using an ERE-luciferase reporter gene; $\mathrm{E}_{2}$ induced the up-regulation of luciferase activity by approximately fourfold in VP229 cells and a weak but reproducible 1·7-fold up-regulation in VP267 cells (data not shown). Finally, $\mathrm{E}_{2}$ was capable of stimulating the proliferation of both VP229 and VP267 cells, but to a lesser extent in VP267 cells $(P<0 \cdot 05$, Fig. 3C). Taken together, these data suggest that VP cell lines express a 

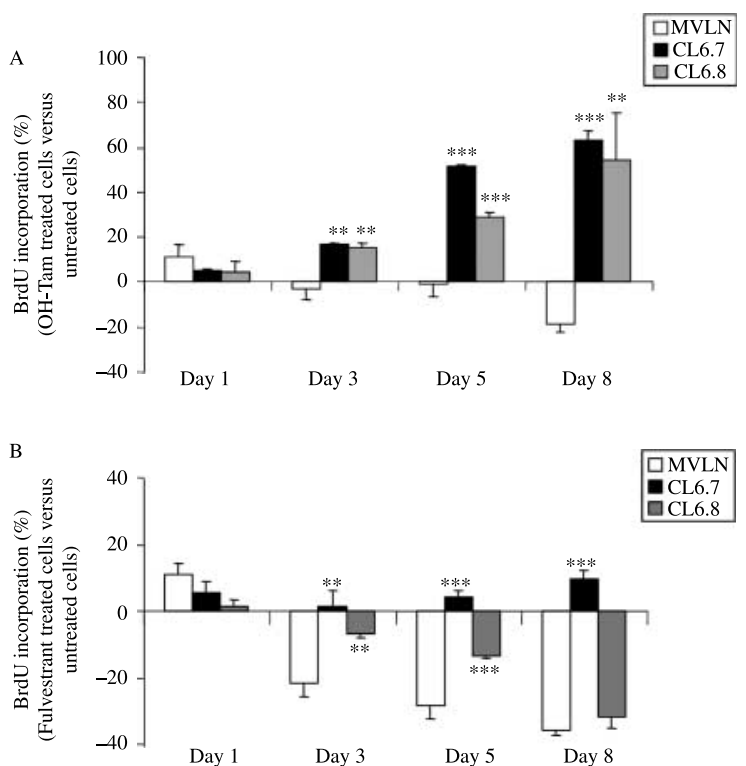

$\mathrm{C}$
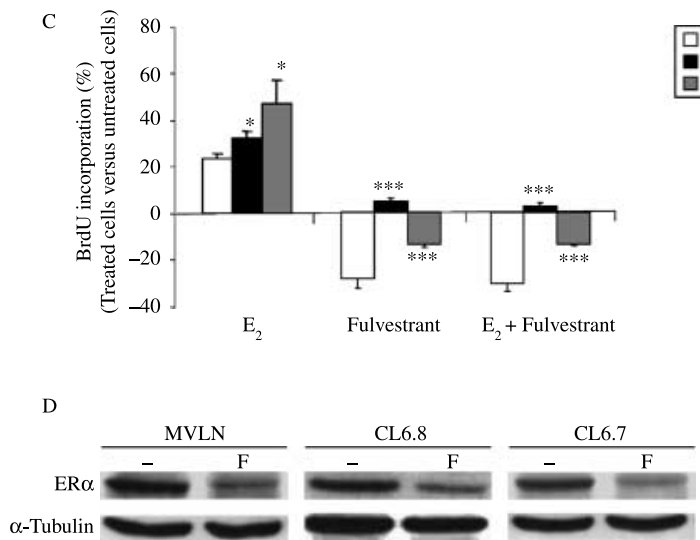

Figure 2 Pharmacological response of MVLN, CL6.7, and CL6.8 cells under $\mathrm{OH}$-Tam and fulvestrant exposure. (A) Proliferative response of MVLN (white bars), CL6.7 (black bars), and CL6.8 (grey bars) cells grown in DCC medium, then treated for $1,3,5$, or 8 days with vehicle or $200 \mathrm{nM} \mathrm{OH}-\mathrm{Tam}$. (B) Proliferative response of MVLN (white bars), CL6.7 (black bars), and CL6.8 (grey bars) cells grown in DCC medium, then treated for $1,3,5$, or 8 days with vehicle or 100 nM fulvestrant. (C) Proliferative response of MVLN (white bars), CL6.7 (black bars), and CL6.8 (grey bars) cells treated for 5 days with vehicle, $1 \mathrm{nME}_{2}, 100 \mathrm{nM}$ fulvestrant or $\mathrm{E}_{2}+$ fulvestrant. Results are expressed as means \pm s.D. from three independent experiments. ${ }^{\star} P<0.05,{ }^{* *} P<0.01$ and ${ }^{* * \star} P<0.001$ versus the corresponding MVLN treatment according to Student's $t$-test. (D) Western-blot analysis of ER $\alpha$ expression in MVLN, CL6.8, and CL6.7 cells under $100 \mathrm{nM}$ fulvestrant $(\mathrm{F})$ exposure as described in the Materials and methods section using anti-ER $\alpha$ antibody. Expression of $\alpha$-tubulin was used as invariant control.

functionally active ER $\alpha$. We then explored cell response to OH-Tam and fulvestrant using a cell proliferation assay. VP229 cells, selected from a patient before any pharmacological treatment, were sensitive to the cytostatic action of both molecules (Fig. 3C). Strikingly, VP267 cells issued from a tumor recurrence under Tam
A
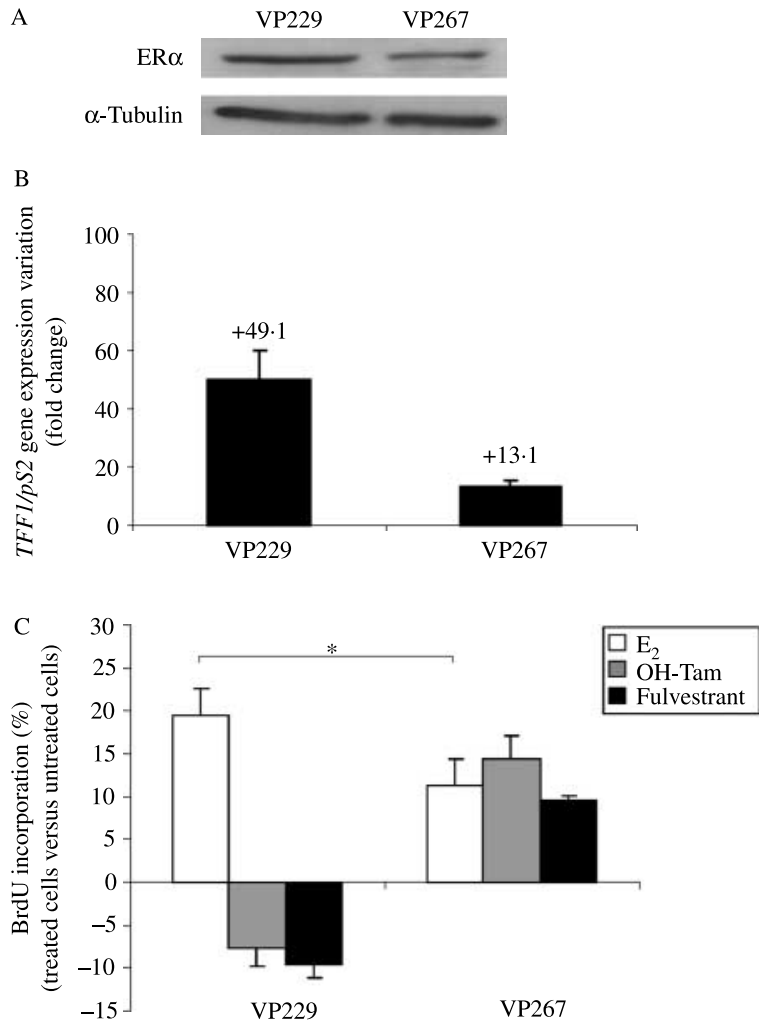

$\mathrm{D}$

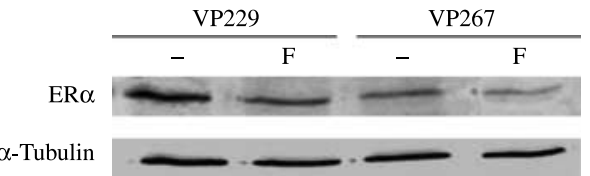

Figure $3 \mathrm{ER} \alpha$ expression and pharmacological response of VP229 and VP267 cell lines. (A) ER $\alpha$ protein expression was analyzed as described in the Materials and methods section using anti-ER $\alpha$ specific antibody. Expression of $\alpha$-tubulin was used as invariant control. (B) TFF1 ( $p S 2)$ gene expression variations (fold change) measured by RTQ-PCR after 4 days of $E_{2}$ treatment of VP229 and VP267. (C) Proliferative response (BrdU labeling) of VP229 and VP267 cells treated for 5 days with vehicle, $1 \mathrm{nM} \mathrm{E}_{2}$ (white bars), $100 \mathrm{nM} \mathrm{OH}$-Tam (grey bars), or $1 \mu \mathrm{M}$ fulvestrant (black bars). ${ }^{*} P<0.05$ versus the corresponding VP229 treatment according to Student's $t$-test. (D) Western blot analysis of the expression of ER $\alpha$ in VP229 and VP267 under $100 \mathrm{nM}$ fulvestrant $(F)$ exposure as described in the Materials and methods section using anti-ER $\alpha$ antibody. Expression of $\alpha$-tubulin was used as invariant control.

treatment developed cross-resistance to both OH-Tam and fulvestrant, and these molecules stimulated VP267 cell proliferation to a degree similar to that induced by $\mathrm{E}_{2}$ (Fig. 3C). As observed for MVLN/CL6.7 cells (Fig. 2D), fulvestrant treatment was capable of inducing a decrease in ER $\alpha$ protein expression in both VP229 and VP267 cell lines (Fig. 3D), suggesting again that the loss of fulvestrant-induced $\mathrm{ER} \alpha$ degradation was not involved in the development of resistance to this molecule in VP267 cells. 


\section{Screening of molecular markers associated with endocrine therapy resistance in MVLN/CL6.7 and VP229/VP267 cells}

As described above, while selected under Tam exposure, CL6.7, and VP267 cells also acquired crossresistance to fulvestrant, characterized by a total abrogation of the SERD's response. Thus, the combination of CL6.7 and VP267 cells represents a good cellular model for the genomic screening of molecular markers of endocrine resistance with potential clinical relevance. To identify deregulation of gene expression associated with resistance to Tam and/or fulvestrant, we selected 26 candidate genes for RTQ-PCR analysis in MVLN/CL6.7 and VP229/VP267 cells. The genes had been identified in our previous studies as estrogenmodulated or associated with agonist activity of OH-Tam and hyper-response to $\mathrm{E}_{2}$ in OTR breast cancer cell lines (Vendrell et al. 2004, 2005). The genes were selected on the basis of the biological function of the encoded proteins: cell proliferation, transformation, apoptosis, DNA repair, and DNA replication.

Analysis of the resulting RTQ-PCR data allowed the selection of 19 genes $(73 \%)$ whose expression was deregulated in at least one of the two resistant cell lines (compared with the sensitive control, Table 2). We identified a variable expression ( $>$ twofold) of 14 genes (54\%) between CL6.7 and MVLN cells and of 13 genes $(50 \%)$ between VP267 and VP229 cells. Eight genes were similarly deregulated in the two resistant cell lines (overexpression of CCNB2, GADD45A, IRS1, $D A P 3$, and $T N F$ and underexpression of CCNE2, EGR2, and TGFB2) and thus might represent common molecular mechanisms developed in vivo or in vitro by breast cancer cells to escape Tam and/or fulvestrant treatment.

In our previous work (Vendrell et al. 2005), we demonstrated that OH-Tam stimulates the proliferation of OTR cells, and that this phenotype is associated with the appearance of an estrogen-like gene-expression signature under $\mathrm{OH}-\mathrm{Tam}$ treatment (i.e. an OH-Tam agonistic action on $\mathrm{E}_{2}$-regulated genes). This was demonstrated for 19 of the 26 genes studied in the present work (genes indicated by asterisks in Table 2). Interestingly, the expression of 13 out of these 19 genes $(68 \%)$ was also deregulated at the basal level in VP267 and/or CL6.7 cells (i.e. comparison of resistant cells to their respective sensitive untreated counterparts). Taken together, these observations suggest that the occurrence of Tam-resistance has, for some genes, consequences on their expression either in the absence or under stimulation by the drug, and that the overall gene-expression variation identified in this study could represent molecular markers possibly associated with the development of endocrine resistance in breast cancer cells.

\section{mRNA expression of the 19 candidate genes, ESR1/ER $\alpha$, and MKI67 in 48 breast tumor samples from patients who relapsed or not under Tam treatment}

With the aim to investigate the clinical relevance of the 19 genes identified as associated with endocrine resistance in CL6.7 and/or VP267, we explored their expression levels in $48 \mathrm{ER}+$ breast tumor samples (Table 1) from postmenopausal women treated with primary surgery followed by adjuvant Tam alone. Twenty-four patients developed acquired resistance to endocrine therapy ('Relapse' group), as they relapsed under Tam treatment and developed metastases (at $1 \cdot 3$ to $10 \cdot 0$ years from surgery), while 24 patients did not ('No relapse' group). Eight out of the 19 candidate genes $(42 \%)$ were significantly overexpressed in the 'Relapse' group compared with the 'No relapse' group $(P<0 \cdot 05$, Kruskal-Wallis test, Table 3): TACC1, NOV, PTTG1, MAD2L1, BAK1, TGFB2, BIRC5, and CCNE2 (Table 3). The capacity of each of these eight genes to discriminate between breast tumors with and without relapse was then tested by ROC curve analysis, i.e. the overall diagnostic values of the eight molecular markers were assessed in terms of their AUC values (Table 3). TACC1, NOV and PTTG1 emerged as the most discriminating markers of relapse on Tam (with ROCAUC curve values of $0 \cdot 899,0 \cdot 819$ and 0.780 respectively). In the same set of $48 \mathrm{ER}+$ tumors, we also examined the expression of the $E S R 1 / E R \alpha$ gene and the MKI67 gene (encoding the proliferation-related Ki-67 antigen) and found that their expression was not significantly different in ER + breast tumors with or without relapse $(P>0 \cdot 05$, Kruskal-Wallis test, Table 3$)$, suggesting that the eight candidate genes were associated with outcome independently of proliferation and $\mathrm{ER} \alpha$ expression status.

\section{Prognostic significance of TACC1, NOV, PTTG1, MAD2L1, BAK1, TGFB2, BIRC5, and CCNE2}

We used univariate analysis (log-rank test) to further study the prognostic value of the eight discriminating genes and to investigate whether their expression level is correlated with prognosis and survival (Table 3). For each gene, the $48 \mathrm{ER}+$ breast tumors were divided into two equal groups of 24 tumors with 'low' (lower than the median mRNA level of the 48 breast tumor samples) and 'high' (higher than the median mRNA level of the 48 breast tumor samples) mRNA levels. Univariate analysis showed that a high expression level of TACC1, NOV, PTTG1, BAK1 and TGFB2 was correlated with significantly shorter RFS (Table 3). The TACC1 gene emerged as the strongest prognostic marker $(P=0.000014$, log-rank test, Table 3 and Fig. 4A). No significant prognostic value was associated 
Table 3 Statistical analysis of mRNA expression of the 19 candidate genes, ESR1/ER $\alpha$ and MKI67 in 24 ER + breast tumors with relapse under Tam treatment relative to $24 \mathrm{ER}+$ breast tumor samples without relapse

\begin{tabular}{|c|c|c|c|c|}
\hline No relapse $(n=24)$ & Relapse $(n=24)$ & $P^{a}$ & ROC-AUC ${ }^{b}$ & Log-rank $^{\mathrm{C}}$ \\
\hline $1.0(0.25-4.56)^{d}$ & $3 \cdot 31(1 \cdot 11-17 \cdot 75)$ & 0.0000021 & 0.899 & 0.000014 \\
\hline $1.0(0.20-3.58)$ & $2 \cdot 71(0.76-6 \cdot 33)$ & 0.00015 & 0.819 & 0.036 \\
\hline $1.0(0.26-2.01)$ & $1.44(0.70-13.95)$ & 0.00087 & 0.780 & 0.014 \\
\hline $1.0(0.46-2.38)$ & $1.47(0.21-6.53)$ & 0.005 & 0.736 & 0.065 (NS) \\
\hline $1.0(0.57-4.34)$ & $1.58(0.76-4.68)$ & 0.0059 & 0.732 & 0.04 \\
\hline $1.0(0.05-37 \cdot 84)$ & $1 \cdot 88(0.43-24.54)$ & 0.01 & 0.717 & 0.032 \\
\hline $1 \cdot 0(0 \cdot 15-7 \cdot 65)$ & $1.99(0.52-17.51)$ & 0.016 & 0.703 & 0.29 (NS) \\
\hline $1.0(0.42-6.22)$ & $2 \cdot 05(0.17-6.24)$ & 0.045 & 0.668 & 0.059 (NS) \\
\hline $1.0(0.09-5.52)$ & $1.46(0.38-8.66)$ & 0.066 (NS) & 0.655 & $\mathrm{ND}^{\mathrm{e}}$ \\
\hline $1.0(0.12-5.00)$ & $1.40(0.52-6.83)$ & 0.068 (NS) & 0.654 & ND \\
\hline $1.0(0.15-48 \cdot 89)$ & $1 \cdot 22(0.23-14.94)$ & 0.12 (NS) & 0.632 & ND \\
\hline $1.0(0.36-4.69)$ & $1.35(0.34-4.35)$ & $0 \cdot 18$ (NS) & 0.614 & ND \\
\hline $1.0(0.51-1.84)$ & $1.05(0.42-2.47)$ & 0.38 (NS) & 0.575 & ND \\
\hline $1.0(0.42-3.14)$ & $1.08(0.68-3.54)$ & 0.39 (NS) & 0.573 & ND \\
\hline $1 \cdot 0(0.14-10 \cdot 25)$ & $1.09(0.19-22 \cdot 82)$ & 0.51 (NS) & 0.556 & ND \\
\hline $1 \cdot 0(0.13-4 \cdot 69)$ & $1 \cdot 17(0 \cdot 36-2 \cdot 22)$ & 0.58 (NS) & 0.546 & ND \\
\hline $1.0(0.04-2.96)$ & $0.92(0.05-4.16)$ & 0.79 (NS) & 0.523 & ND \\
\hline $1.0(0.19-2 \cdot 22)$ & $1.02(0.23-3.64)$ & 0.98 (NS) & 0.503 & ND \\
\hline $1.0(0.19-6.92)$ & $0.86(0.25-5.01)$ & 0.86 (NS) & 0.485 & ND \\
\hline $1.0(0.11-4 \cdot 18)$ & $0.88(0.33-4.12)$ & 0.68 (NS) & 0.465 & ND \\
\hline $1.0(0.08-4.01)$ & $0.55(0.10-2 \cdot 18)$ & 0.23 (NS) & 0.398 & ND \\
\hline
\end{tabular}

NS, not significant.

${ }^{a}$ Kruskal-Wallis Test.

${ }^{\mathrm{b}} \mathrm{ROC}$, receiver operating characteristics; AUC, area under curve analysis.

'Log-rank test.

${ }^{\mathrm{d}}$ Median (range) of gene mRNA levels (normalized such that the median of the mRNA levels of the six normal breast samples would equal a value of 1 ).

eNot determined.

with BIRC5, nor with MAD2L1 and CCNE2 although there was a trend toward significance $(P=0 \cdot 065$ and $P=0.059$ respectively, log-rank test, Table 3 ). Hierarchical clustering of the 48 tumor samples based on the expression of TACC1, NOV and PTTG1 allowed the separation of the samples into two groups (groups A and B) with significantly different outcomes $\left(P c h i^{2}=0 \cdot 0000002\right.$; Fig. 4B): group A $(n=24)$ with good clinical outcome (only 3 out of the 24 samples, i.e. $12.5 \%$, belonged to the 'Relapse' group and were misclassified) and group B $(n=24)$ with poor clinical outcome (21 of the 24 samples of this group, i.e. $87.5 \%$, belonged to the 'Relapse' group and were thus correctly classified). The prognostic value of this three-gene expression signature was higher than the prognostic value of TACC1 alone $(P=0.0000017, \log$-rank test, Fig. 4C). Finally, using a Cox proportional hazards model, we also assessed the prognostic value for RFS of parameters that were significant or near significant $(P<0 \cdot 1)$ in univariate analysis, i.e. lymph-node status, macroscopic tumor size (Table 1), and TACC1 alone (Fig. 4A) or the three-gene signature (Fig. 4C). Only the prognostic significance of TACC1 alone and the threegene signature persisted in Cox multivariate regression analysis of RFS $(P=0 \cdot 0002$ and $P=0 \cdot 0001$ respectively $)$.
mRNA expression of TACC1, NOV, and PTTG1 in response to $\mathrm{OH}$-Tam or to fulvestrant exposure in the sensitive cell line MVLN and the cross-resistant cell line CL6.7

To further investigate the potential endocrine responsiveness of TACC1, NOV, and PTTG1 gene expression, we analyzed by RTQ-PCR the mRNA levels of the three genes in MVLN and CL6.7 cells after 4 days of $\mathrm{E}_{2}$, OH-Tam or fulvestrant treatment (Fig. 5). Like TFF1/ pS2 (Fig. 1B), TACC1, NOV, and PTTG1 responded to $\mathrm{E}_{2}$ in both MVLN and CL6.7 cells (greater than twofold regulation; Fig. 5). The expression of TACC1 and $N O V$ was down-regulated under $\mathrm{E}_{2}$ exposure while PTTG1 mRNA levels were up-regulated. In MVLN cells, none of the variations produced by the pharmacological action of $\mathrm{E}_{2}$ were observed on fulvestrant. On the contrary, fulvestrant seemed to display a 'reversed' pharmacology, as treatment induced reproducible down-regulation of PTTG1 gene expression (which was up-regulated under $\mathrm{E}_{2}$ treatment) and reproducible up-regulation of TACC1 and NOV gene expression (down-regulated by $\mathrm{E}_{2}$ ). The OH-Tam signature in MVLN cells was different from that of $\mathrm{E}_{2}$ as NOV and PTTG1 genes did not display any variation 

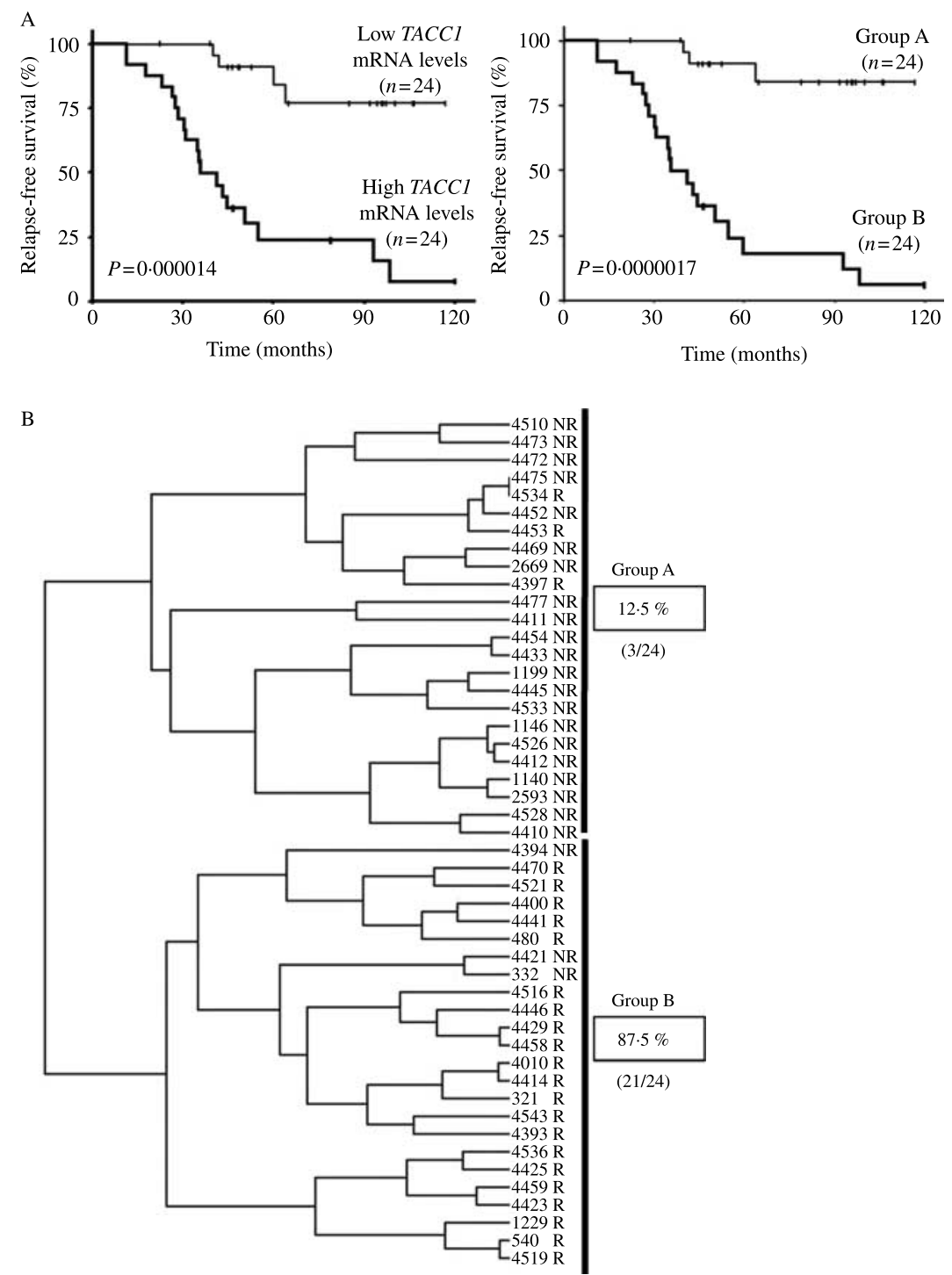

Figure 4 Prognostic value of TACC1 expression or three-gene (TACC1, NOV, and PTTG1) expression signature. (A) Relationship between RFS and TACC1 expression in a series of $48 \mathrm{ER}+$ breast tumor samples. (B) Dendogram of $48 \mathrm{ER}+$ breast tumor samples from patients who relapsed $(R, n=24)$ or did not relapse $(N R, n=24)$ under Tam treatment, constructed by hierarchical clustering according to the expression of TACC1, NOV, and PTTG1, and allowing the emergence of two groups: group $\mathrm{A}(n=24)$ and group $B(n=24)$. Percentage of patients who relapsed $(R)$ in groups $A$ and $B$ are indicated on the right. (C) Relationship between RFS and the three-gene expression signature (TACC1, NOV, and PTTG1) in a series of $48 \mathrm{ER}+$ breast tumor samples. Groups A and B correspond to the groups defined in Fig. 4B.

of expression. It was also different from that of fulvestrant as no 'reversed' pharmacology was observed. Finally, we detected in MVLN cells a partial agonistic action of OH-Tam on the TACC1 gene, evidenced by a down-regulated expression on $\mathrm{E}_{2}$ or $\mathrm{OH}-\mathrm{Tam}$ treatment. Interestingly, the pharmacological responsiveness to endocrine therapy observed for the three genes in MVLN cells was totally impaired in resistant CL6.7 cells. Indeed, in these cells, OH-Tam treatment had no impact on TACC1 gene expression and the 'reversed' pharmacology of fulvestrant observed for TACC1, NOV, and PTTG1 in MVLN cells was also totally abrogated. Taken together these data support the hypothesis that TACC1, NOV, and PTTG1 are candidate molecular markers associated with deregulated endocrine therapy responsiveness. 

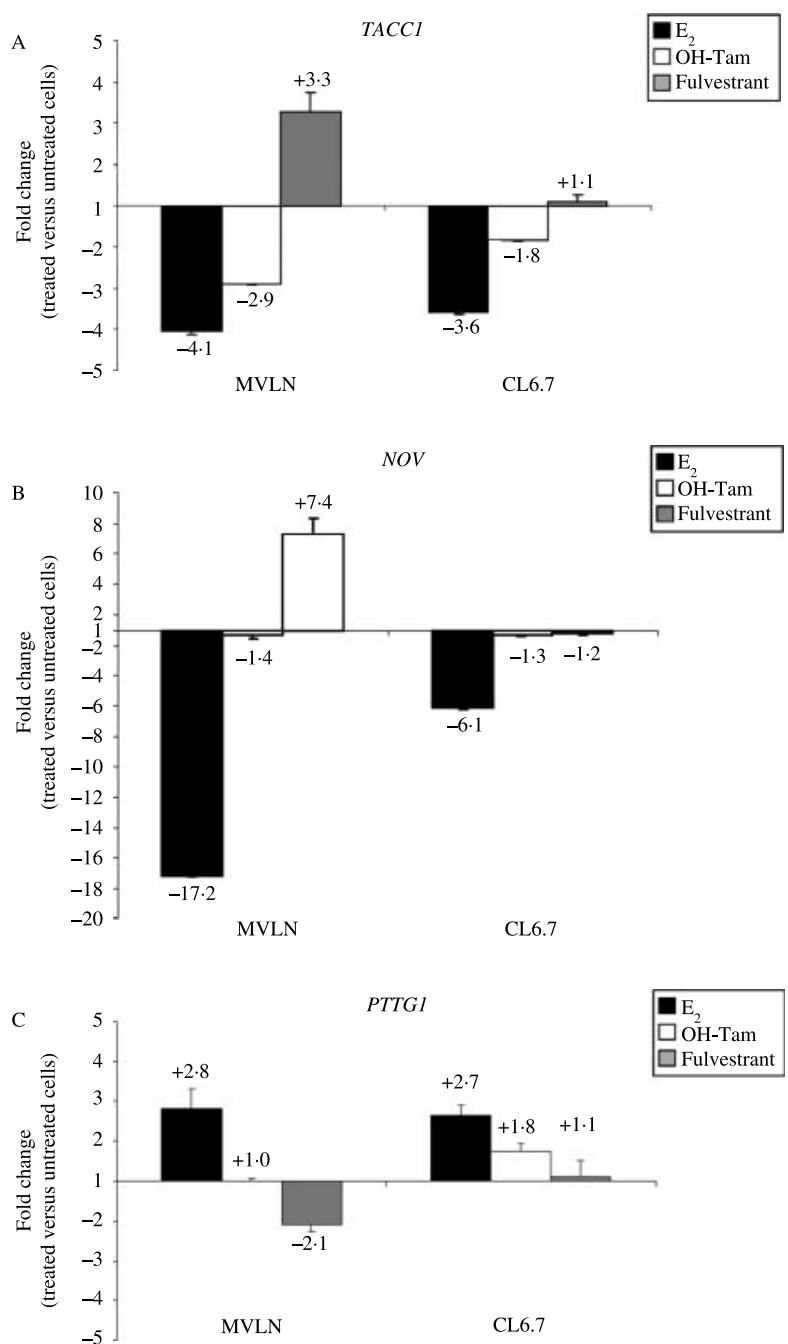

Figure 5 mRNA levels of TACC1, NOV, and PTTG1 in MVLN and CL6.7 cells under $\mathrm{E}_{2}, \mathrm{OH}-\mathrm{Tam}$, and fulvestrant exposure. The gene expression variations (fold change) of (A) TACC1, (B) NOV and (C) PTTG1 were measured by RTQ-PCR after 4 days of culture in DCC medium or under $1 \mathrm{nM} \mathrm{E}_{2}$ (black bars), $200 \mathrm{nM}$ $\mathrm{OH}-\mathrm{Tam}$ (white bars), or $100 \mathrm{nM}$ fulvestrant (grey bars). The RTQ-PCR values indicated are the means of at least three independent experiments. Gene-expression variation was considered significant for $\mathrm{FC} \geq 2$ or $\mathrm{FC} \leq-2$.

\section{Concordance between mRNA expression levels and protein expression levels of TACC1, NOV, and PTTG1 in cell lines and breast tumor samples}

With the aim to assess the functional relevance of the biomarkers identified in this study, we explored the protein expression levels of TACC1, NOV, and PTTG1 using specific commercially available antibodies. We aimed, first, to explore whether the TACC1, NOV, and PTTG1 gene products are expressed at the protein level, and second, whether mRNA and protein levels are concordant. The data presented in Fig. 6A demonstrate that all the deregulations of expression of TACC1, NOV, or PTTG1 genes identified at the basal level in the resistant CL6.7 or VP267 cell lines, when compared with their respective sensitive cell line (Table 2), were validated by western blot analysis. In OH-Tam- or fulvestrant-treated MVLN and CL6.7 cells, most of the deregulated expression of TACC1, NOV, and PTTG1 observed at the mRNA level (Fig. 5) and associated with aberrant endocrine therapy responsiveness was also validated at the protein level by western blot analysis (Fig. 6B). Taken together, these results demonstrate that in MVLN/CL6.7 and in VP229/VP267 cell lines, there is a very good concordance between deregulations of expression of TACC1, NOV, and PTTG1 at the mRNA level and at the protein level.

The expression of the three candidate proteins identified above was assessed by immunohistochemistry, using antibodies directed against TACC1, NOV, or PTTG1, in $10 \mathrm{ER}+$ breast tumor samples. In contrast to stromal cells, specific positive staining was observed in tumor cells using the antibodies directed against NOV or PTTG1 (Fig. 7). For the two proteins, the staining was localized only within the cytoplasm (Fig. 7). Unfortunately, unspecific staining was obtained with the TACC1 antibody used in this study, thus preventing the interpretation of immunohistochemistry data. Finally, when exploring the mRNA and protein expression levels of NOV and PTTG1 in each of the 10 tumor samples, we found that $80 \%(8 / 10)$ and $70 \%$ $(7 / 10)$ respectively, of the tested samples had been correctly classified into the 'low' or the 'high' expression groups, both at the mRNA and the protein levels. Altogether, these data demonstrate, first, that TACC1, NOV, and PTTG1 gene products are expressed and, secondly, that there is a good concordance between mRNA and protein levels for TACC1, NOV, and PTTG1 in breast cancer cell lines, and at least for NOV and PTTG1 in breast tumor samples.

\section{Discussion}

Impressive early results obtained with tamoxifen in the adjuvant setting led clinicians to use tamoxifen as neoadjuvant therapy to avoid surgery in elderly women with ER+ cancer (Horobin et al. 1991). However, longterm follow-up and clinical trials have demonstrated that up to $62 \%$ of cancers initially responsive to endocrine therapy subsequently escape control, with the patient requiring salvage surgery (Horobin et al. 1991, Fennessy et al. 2004). With the aim to circumvent the development of endocrine resistance and to delay chemotherapy, several clinical trials have investigated the best sequence of administration of the different molecules available for endocrine therapy as first-, second-, or third-line treatment (Howell et al. 2002, Osborne et al. 2002, Dodwell \& 
A

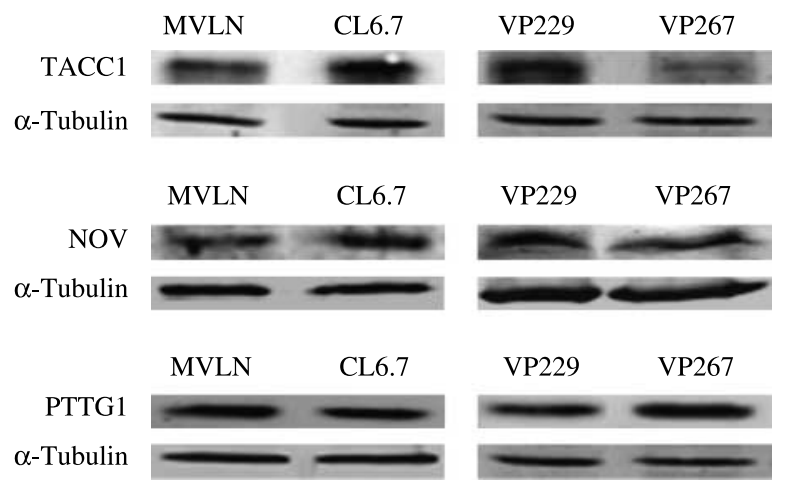

B

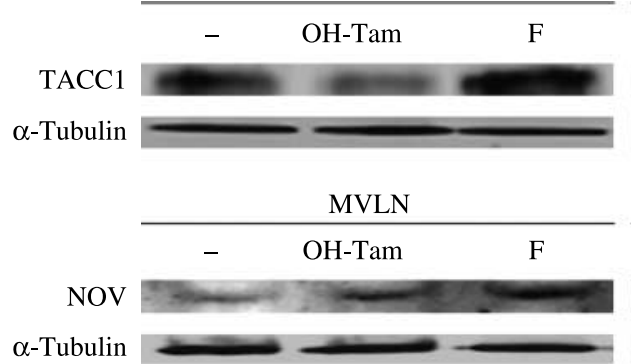

MVLN

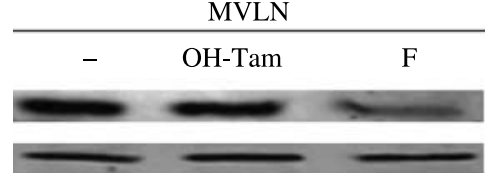

$\alpha$-Tubulin
CL6.7

\begin{tabular}{|c|c|c|}
\hline- & OH-Tam & $\mathrm{F}$ \\
\hline & CL6.7 & \\
\hline- & OH-Tam & $\mathrm{F}$ \\
\hline
\end{tabular}

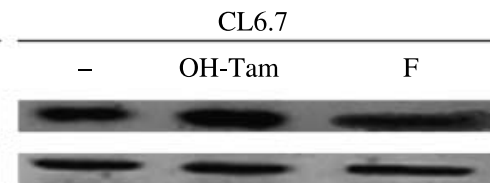

Figure 6 Protein detection of TACC1, NOV, and PTTG1 in MVLN/CL6.7 and VP229/VP267 cellular models of endocrine resistance. Western blot analysis of TACC1, NOV, and PTTG1 expression in (A) MVLN, CL6.7, VP229, and VP267 cells under basal condition and in (B) MVLN and CL6.7 under $200 \mathrm{nM} \mathrm{OH-Tam} \mathrm{or} 100 \mathrm{nM}$ fulvestrant (F) exposure. Expression of $\alpha$-tubulin was used as invariant control.

Pippen 2006, Perey et al. 2007). Treatment with the SERD fulvestrant has proven effective upon progression on Tam but, as for Tam treatment in advanced breast cancer, resistance will inevitably occur. The molecular changes associated with fulvestrant resistance are only beginning to emerge, but previous studies have identified several proteins possibly associated with the fulvestrant resistant phenotype in cell lines: EGFR, Erbb2, Erbb3, and Erk (McClelland et al. 2001, Fan et al. 2006a, Frogne et al. 2008), Akt (Frogne et al. 2005), and NFкB (Gu et al. 2002). One study has analyzed global gene expression in Tam-resistant and fulvestrant-resistant MCF-7 cells and suggested that while Tam resistance preferentially alters the expression of genes downstream of ER, fulvestrant resistance is characterized by a strong remodeling of gene expression (Fan et al. 2006a).

As fulvestrant is now approved for second-line treatment after failure of Tam or aromatase inhibitors, the next challenge is identifying molecular changes associated with the development of cross-resistance to fulvestrant and thus valuable cellular models for fulvestrant cross-resistance acquisition are urgently needed. The development of such a phenotype is rarely described, as noted above. Only few studies have reported the decreased sensitivity of Tam-resistant breast cancer cells or xenografts to fulvestrant (Lykkesfeldt et al. 1994, Naundorf et al. 2000), but none, to our knowledge, has demonstrated the total loss of sensitivity to this SERD.

Our data show for the first time that both MVLN/CL6.7 and VP229/VP267 cell lines are valuable cellular models to investigate cross-resistance to endocrine therapy. Indeed, while selected in the presence of OH-Tam (or Tam) alone, CL6.7 and VP267 cells also acquired cross-resistance to fulvestrant, characterized by the total loss of fulvestrant response. Our study also demonstrated that such phenomenon can occur under in vitro (MVLN/CL6.7 cells) or in vivo (VP229/VP267 

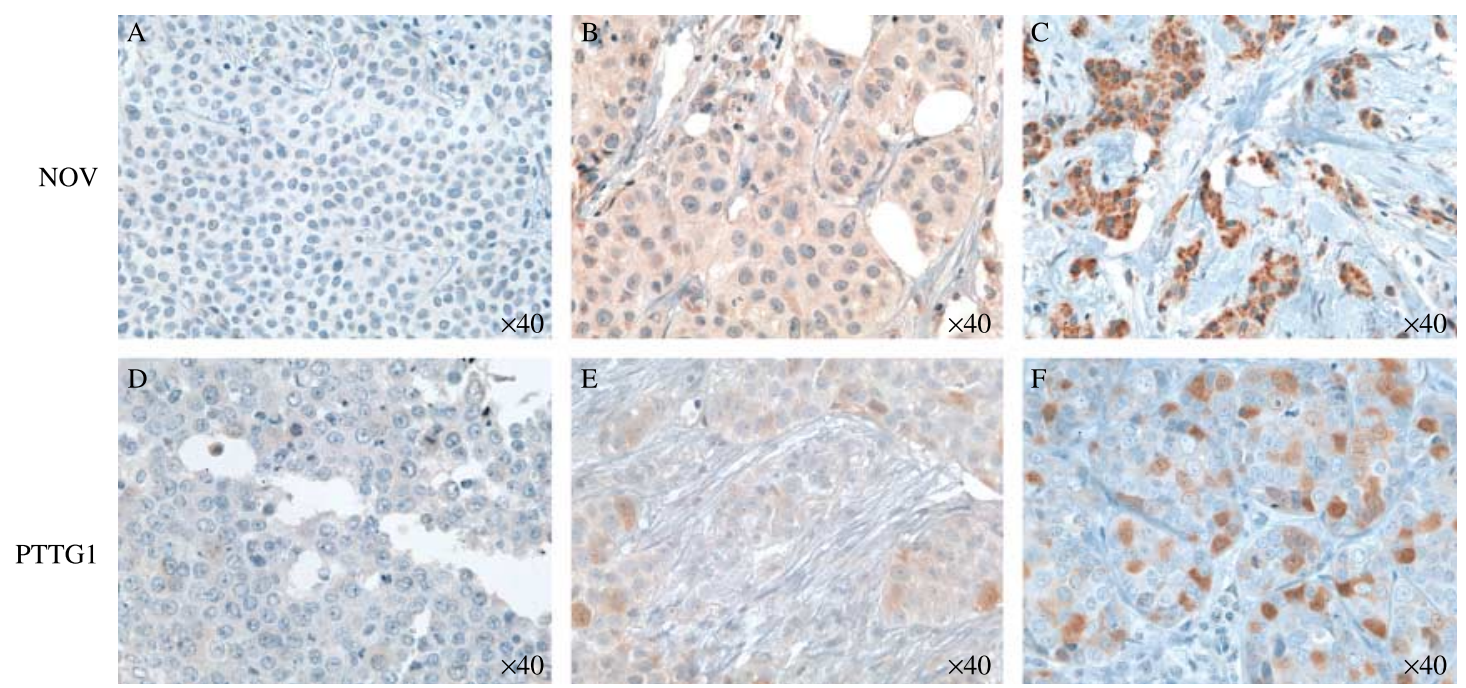

Figure 7 Analysis of NOV and PTTG1 expression in breast infiltrative carcinomas using immunohistochemistry. All images were taken at x40 magnification. (A) undetectable NOV expression level represented by the absence of cytoplasmic staining, (B) low NOV expression level represented by a focal $1+$ cytoplasmic staining, (C) high NOV expression level represented by a diffuse $3+$ cytoplasmic staining, (D) undetectable PTTG1 expression level represented by the absence of cytoplasmic staining, (E) low PTTG1 expression level represented by a $1+$ cytoplasmic staining, and (F) high PTTG1 expression level represented by a $2+$ cytoplasmic staining.

cells) selection. We also showed that acquisition of such phenotype was not due to any loss in $\mathrm{ER} \alpha$ functionality or any loss in fulvestrant binding to ER $\alpha$. Finally, our study also suggests that under the same selection process (OH-Tam selection), the resulting resistant cellular clones can display different endocrine therapy resistance phenotypes, as demonstrated for the two cellular clones CL6.8 and CL6.7 which, while issued from the same selection process (Vendrell et al. 2005), developed different modes of acquisition of resistance to endocrine therapy: OH-Tam resistance only (CL6.8 cells) or cross-resistance to OH-Tam and fulvestrant (CL6.7 cells). This probably reflects the heterogeneity of breast cancer cells in tumors having acquired resistance to first-line Tam endocrine therapy and thus suggests that, in these tumors, cells that will be refractory to fulvestrant second-line therapy are already present after the first selection. This has important clinical consequences because, while the difference between the mechanisms of action of Tam and fulvestrant (Wakeling et al. 1991, Tzukerman et al. 1994, McDonnell et al. 1995, Dowsett et al. 2005) supports the use of fulvestrant as second-line treatment in Tam-resistant patients (Howell et al. 2002, Osborne et al. 2002), cross-resistance to fulvestrant may also occur in Tam-resistant patients. Thus, there is a pressing need for identifying general biomarkers of endocrine therapy resistance to help in the clinical management of such patients.

As MVLN/CL6.7 cells and VP229/VP267 cell lines are original and valuable models of cross-resistance to Tam and fulvestrant, identifying gene expression deregulations in these cell lines would represent a significant step towards the identification of new biomarkers. Of the 26 genes screened by RTQ-PCR, 19 displayed a deregulation of expression in at least one of the two cross-resistant cell lines tested, and two, TGFB2 and TGFBR2, have also been recently identified in in vitro models of Tam- or fulvestrant-resistance (Fan et al. 2006a). Several genes (CCNB2, CCNE2, EGR2, GADD45A, IRS1, DAP3, TGFB2, and TNF) which were found similarly deregulated in both resistant cell lines, might represent common molecular mechanisms developed in vivo and in vitro by breast cancer cells to escape Tam and/or fulvestrant treatment. Indeed, all of these genes belong to two functional clusters previously described as associated with poor endocrine response (Paik et al. 2004, Jansen et al. 2005, Chanrion et al. 2008): CCNB2, CCNE2, EGR2, GADD45A, and IRS1 belong to the cell proliferation functional cluster and $D A P 3, T G F B 2$, and $T N F$ to the apoptosis functional cluster. A supporting observation is that CCNB2 has previously been described as part of a 36-gene signature predictive of Tam recurrence (Chanrion et al. 2008).

In a well-defined cohort of 48 relapsing or nonrelapsing ER + postmenopausal breast cancer patients treated with primary surgery followed by adjuvant Tam alone, we found that 8 out of the 19 genes selected on cross-resistant breast cancer cells (TACC1, NOV, PTTG1, $M A D 2 L 1, B A K 1, T G F B 2, B I R C 5$, and CCNE2) were significantly overexpressed in the group of patients who relapsed under Tam treatment $(P<0 \cdot 05$, KruskalWallis test). Interestingly, 3 out of these 8 are mitotic checkpoint genes (TACC1, PTTG1, and MAD2L1). 
BIRC5 also belongs to the 21-gene Tam recurrence signature described by Paik and colleagues (Paik et al. 2004), and CCNE2 to the 70-gene prognostic signature identified by van 't Veer et al. (2002).

In the present work, multivariate analysis demonstrated that TACC1 alone and the three-gene expression signature TACC1, NOV, and PTTG1 were independent prognostic markers (log-rank test, Cox multivariate analysis). The transforming acidic coiled coil 1 (TACC1), which emerged as the strongest prognostic marker, is a putative oncogene located within a breast cancer amplicon found on human chromosome 8p11 (Still et al. 1999) which we have previously identified as a new estrogen-regulated gene (Vendrell et al. 2004). The TACC1 protein is involved in mitotic checkpoint regulation through stabilization of microtubules in the growing spindle, and interacts with the Aurora A/STK6 kinase (Conte et al. 2003). TACC1 can transform fibroblasts (Still et al. 1999), and recent work has shown that it promotes transformation and mammary tumorigenesis through positive regulation with the Ras and PI3K signaling pathways (Cully et al. 2005), both also involved in the development of Tam resistance (for review, Moy \& Goss 2006). More interestingly, high levels of amplification of the $8 \mathrm{p} 11$ region (encoding the TACC1 gene) have been significantly associated with reduced survival duration or distant recurrence in breast cancer (Chin et al. 2006). NOV (neuroblastoma overexpressed gene), which encodes a negative regulator of cell proliferation, can be involved in tumorigenesis (Scholz et al. 1996). In a previous work, we have identified NOVas a new estrogen-regulated gene (Vendrell et al. 2004) and also a gene on which Tam exerts an estrogen-like activity in Tam-resistant breast cancer cells (Vendrell et al. 2005). Several studies have reported an association between low expression levels of $\mathrm{NOV}$ and progression of adrenocortical tumors (Martinerie et al. 2001), renal cell carcinoma (Niu et al. 2005), and poor breast cancer prognosis (Jiang et al. 2004). In this study, we show that high expression levels of NOVare associated with endocrine therapy crossresistance in CL6.7 cells (Table 2) and endocrine therapy resistance in breast tumor samples (Table 3). Further investigations are needed to explain this specific point. Finally, PTTG1 (pituitary tumor-transforming gene 1, also called Securin) encodes a regulatory protein that plays a central role in mitotic checkpoint control, chromosome stability, the p53 pathway and DNA repair. PTTG1 negatively regulates the transcriptional activity and related apoptotic activity of p53, which explains the strong transforming capability of this protein when it is overexpressed (Bernal et al. 2002). In a previous work, we have demonstrated that PTTG1 gene expression is associated with hypersensitivity to $\mathrm{E}_{2}$ and agonist-like activity of Tam in Tam-resistant breast cancer cells (Vendrell et al. 2005). Recently, two single-nucleotide polymorphisms in the PTTG1 gene have been associated with increased risk of breast cancer (Lo et al. 2007). Furthermore, increased expression of PTTG1 has been correlated with poor prognosis in glioma patients and in hepatocellular carcinoma (Fujii et al. 2006, Genkai et al. 2006).

Taken together, these data provide evidence that TACC1, NOV, and PTTG1 genes are new biomarkers associated with endocrine therapy resistance in breast cancer. None of these three genes belongs to the 21-gene Tam recurrence signature described by Paik and colleagues (Paik et al. 2004), to the gene expression signature that predicts the clinical outcome of breast cancer patients treated with tamoxifen (Jansen et al. 2005), to the two-gene signature described by Ma and colleagues (Ma et al. 2004), or to the predictive gene expression signature of Tam recurrence defined more recently by Chanrion and colleagues (Chanrion et al. 2008). Fan et al. (2006b) have compared the predictions derived from five gene expression profiling studies and suggested that, even though there is little gene overlap between the different studies using different algorithms, the outcome predictions are similar and probably track the same phenotype. This suggests that although there is no overlap between the present study and other published studies, the three genes selected here may still be compatible. The supporting argument is that these three genes belong to a functional cluster (proliferation/transformation) present in previously published classifiers (van 't Veer et al. 2002, Paik et al. 2004, Jansen et al. 2005, Chanrion et al. 2008).

In conclusion, the identification of more specific new markers to better predict breast cancer outcome and response to endocrine therapy appears fundamental and clinically useful, as it would allow personalizing the patient's treatment. Genomic approaches based on large-scale experiments have been successfully used in breast cancer tumors to identify prognostic markers such as aberrant gene expression signatures or genomic alterations associated with Tam failure (Ma et al. 2004, Paik et al. 2004, Jansen et al. 2005, Han et al. 2006, Chanrion et al. 2008). An alternative approach is based on the exploration of a limited number of candidate genes by RTQ-PCR. This technique, which focuses on a small number of genes, has already proved useful for the identification of candidate gene expression signatures with prognostic significance. Using RTQ-PCR, Paik and colleagues have been able to identify a 21-gene signature that could predict recurrence of tamoxifentreated breast cancer (Paik et al. 2004). In this study, we selected candidate genes identified by previous cDNA array experiments and we explored by RTQ-PCR their expression in cellular models of endocrine therapy cross-resistance and in breast tumor samples. We were able to identify TACC1, NOV, and PTTG1 as prognostic markers associated with endocrine therapy resistance in breast tumor samples. Future work on a larger cohort is needed to validate their prognostic value but also their 
predictive value for fulvestrant response in patients developing resistance to first-line Tam treatment. Moreover, as aromatase inhibitors may replace Tam for first-line therapy in postmenopausal women, investigating the expression of these new biomarkers in aromatase inhibitor-resistant breast tumor samples would be very informative, as it would allow to delineate the overlap between expression signatures of resistance to ER-ligands (Tam and fulvestrant) and to aromatase inhibitors. Encouraging results have been obtained, since we have shown a good correlation between the mRNA and protein levels of TACC1, NOV, and PTTG1 in cell lines and/or breast tumor samples, suggesting that they could be considered as candidate protein markers for immunohistochemical analysis. The present work is thus a first step towards the identification of new biomarkers associated with endocrine resistance that could be used in the clinical management of ER+ breast cancer patients.

\section{Declaration of interest}

All co-authors declare that there is no conflict of interest that could be perceived as prejudicing the impartiality of the research report.

\section{Funding}

This work was supported by grants from the Ligue Nationale Contre le Cancer (Comité de l'Ardèche, Comité de la Saône et Loire, Comité de Savoie) and from ARC (Association pour la Recherche sur le Cancer). S E Ghayad was supported by a fellowship from the Ministère de l'Education Nationale et de l'Enseignement Supérieur (France) and a grant from the ARC (Association pour la Recherche sur le Cancer).

\section{Acknowledgements}

We are grateful to Dr E Badia for providing the MVLN, CL6.8 and CL6.7 cells and to Dr H D McCallum for providing the VP cells. We thank S Leon-Goddard for help in immunohistochemistry experiments. We also thank M D Reynaud for editing the manuscript.

\section{References}

Badia E, Duchesne MJ, Semlali A, Fuentes M, Giamarchi C, RichardFoy H, Nicolas JC \& Pons M 2000 Long-term hydroxytamoxifen treatment of an MCF-7-derived breast cancer cell line irreversibly inhibits the expression of estrogenic genes through chromatin remodeling. Cancer Research 60 4130-4138.

Bernal JA, Luna R, Espina A, Lazaro I, Ramos-Morales F, Romero F, Arias C, Silva A, Tortolero M \& Pintor-Toro JA 2002 Human securin interacts with p53 and modulates p53-mediated transcriptional activity and apoptosis. Nature Genetics 32 306-311.

Bieche I, Tozlu S, Girault I \& Lidereau R 2004 Identification of a threegene expression signature of poor-prognosis breast carcinoma. Molecular Cancer 337.

Bloom HJ \& Richardson WW 1957 Histological grading and prognosis in breast cancer; a study of 1409 cases of which 359 have been followed for 15 years. British Journal of Cancer 11 359-377.
Brunner N, Boysen B, Jirus S, Skaar TC, Holst-Hansen C, Lippman J, Frandsen T, Spang-Thomsen M, Fuqua SA \& Clarke R 1997 MCF7/LCC9: an antiestrogen-resistant MCF-7 variant in which acquired resistance to the steroidal antiestrogen ICI 182,780 confers an early cross-resistance to the nonsteroidal antiestrogen tamoxifen. Cancer Research 57 3486-3493.

Chanrion M, Negre V, Fontaine H, Salvetat N, Bibeau F, Mac Grogan G, Mauriac L, Katsaros D, Molina F, Theillet C et al. 2008 A gene expression signature that can predict the recurrence of tamoxifentreated primary breast cancer. Clinical Cancer Research 14 1744-1752.

Chin K, DeVries S, Fridlyand J, Spellman PT, Roydasgupta R, Kuo WL, Lapuk A, Neve RM, Qian Z, Ryder T et al. 2006 Genomic and transcriptional aberrations linked to breast cancer pathophysiologies. Cancer Cell 10 529-541.

Conte N, Delaval B, Ginestier C, Ferrand A, Isnardon D, Larroque C, Prigent C, Seraphin B, Jacquemier J \& Birnbaum D 2003 TACC1chTOG-Aurora A protein complex in breast cancer. Oncogene 22 8102-8116.

Cox DR 1972 Regression models and life-tables. Journal of the Royal Statistical Society: Series B 34 187-220.

Cully M, Shiu J, Piekorz RP, Muller WJ, Done SJ \& Mak TW 2005 Transforming acidic coiled coil 1 promotes transformation and mammary tumorigenesis. Cancer Research 65 10363-10370.

Dauvois S, Danielian PS, White R \& Parker MG 1992 Antiestrogen ICI 164,384 reduces cellular estrogen receptor content by increasing its turnover. PNAS 89 4037-4041.

Demirpence E, Duchesne MJ, Badia E, Gagne D \& Pons M 1993 MVLN cells: a bioluminescent MCF-7-derived cell line to study the modulation of estrogenic activity. Journal of Steroid Biochemistry and Molecular Biology 46 355-364.

Didier G, Brezellec P, Remy E \& Henaut A 2002 GeneANOVA - gene expression analysis of variance. Bioinformatics 18 490-491.

Dodwell D \& Pippen J 2006 Time to response: comparison of fulvestrant and oral endocrine agents. Clinical Breast Cancer 7 244-247.

Dowsett M, Nicholson RI \& Pietras RJ 2005 Biological characteristics of the pure antiestrogen fulvestrant: overcoming endocrine resistance. Breast Cancer Research and Treatment 93 S11-S18.

EBCTC Group 1998 Tamoxifen for early breast cancer: an overview of the randomised trials. Early Breast Cancer Trialists' Collaborative Group. Lancet 351 1451-1467.

Elston EW \& Ellis IO 1993 Method for grading breast cancer. Journal of Clinical Pathology 46 189-190.

Fan M, Bigsby RM \& Nephew KP 2003 The NEDD8 pathway is required for proteasome-mediated degradation of human estrogen receptor (ER)-alpha and essential for the antiproliferative activity of ICI 182,780 in ERalpha-positive breast cancer cells. Molecular Endocrinology 17 356-365.

Fan M, Yan PS, Hartman-Frey C, Chen L, Paik H, Oyer SL, Salisbury JD, Cheng AS, Li L, Abbosh PH et al. 2006 a Diverse gene expression and DNA methylation profiles correlate with differential adaptation of breast cancer cells to the antiestrogens tamoxifen and fulvestrant. Cancer Research 66 11954-11966.

Fan C, Oh DS, Wessels L, Weigelt B, Nuyten DS, Nobel AB, van't Veer LJ \& Perou CM $2006 b$ Concordance among gene-expression-based predictors for breast cancer. New England Journal of Medicine $\mathbf{3 5 5}$ $560-569$.

Fennessy M, Bates T, MacRae K, Riley D, Houghton J \& Baum M 2004 Late follow-up of a randomized trial of surgery plus tamoxifen versus tamoxifen alone in women aged over 70 years with operable breast cancer. British Journal of Surgery 91 699-704.

Frasor J, Chang EC, Komm B, Lin CY, Vega VB, Liu ET, Miller LD, Smeds J, Bergh J \& Katzenellenbogen BS 2006 Gene expression preferentially regulated by tamoxifen in breast cancer cells and correlations with clinical outcome. Cancer Research 66 7334-7340.

Frogne T, Jepsen JS, Larsen SS, Fog CK, Brockdorff BL \& Lykkesfeldt AE 2005 Antiestrogen-resistant human breast cancer cells require activated protein kinase B/Akt for growth. Endocrine-Related Cancer 12 599-614. 
Frogne T, Benjaminsen RV, Sonne-Hansen K, Sorensen BS, Nexo E, Laenkholm AV, Rasmussen LM, Riese DJ II, de Cremoux P, Stenvang J et al. In Press Activation of ErbB3, EGFR and Erk is essential for growth of human breast cancer cell lines with acquired resistance to fulvestrant. Breast Cancer Research and Treatment. In Press, DOI: 10.1007/S10549-008-0011-8.

Fujii T, Nomoto S, Koshikawa K, Yatabe Y, Teshigawara O, Mori T, Inoue S, Takeda S \& Nakao A 2006 Overexpression of pituitary tumor transforming gene 1 in HCC is associated with angiogenesis and poor prognosis. Hepatology 43 1267-1275.

Genkai N, Homma J, Sano M, Tanaka R \& Yamanaka R 2006 Increased expression of pituitary tumor-transforming gene (PTTG)-1 is correlated with poor prognosis in glioma patients. Oncology Reports 15 1569-1574.

Girault I, Tozlu S, Lidereau R \& Bieche I 2003 Expression analysis of DNA methyltransferases $1,3 \mathrm{~A}$, and $3 \mathrm{~B}$ in sporadic breast carcinomas. Clinical Cancer Research 9 4415-4422.

Gradishar WJ 2005 Safety considerations of adjuvant therapy in early breast cancer in postmenopausal women. Oncology 69 1-9.

Gu Z, Lee RY, Skaar TC, Bouker KB, Welch JN, Lu J, Liu A, Zhu Y, Davis $\mathrm{N}$, Leonessa F et al. 2002 Association of interferon regulatory factor1, nucleophosmin, nuclear factor-kappaB, and cyclic AMP response element binding with acquired resistance to Faslodex (ICI 182,780). Cancer Research 62 3428-3437.

Han W, Han MR, Kang JJ, Bae JY, Lee JH, Bae YJ, Lee JE, Shin HJ, Hwang KT, Hwang SE et al. 2006 Genomic alterations identified by array comparative genomic hybridization as prognostic markers in tamoxifen-treated estrogen receptor-positive breast cancer. BMC Cancer 692.

Hanley JA \& McNeil BJ 1982 The meaning and use of the area under a receiver operating characteristic (ROC) curve. Radiology 143 29-36.

Horobin JM, Preece PE, Dewar JA, Wood RA \& Cuschieri A 1991 Longterm follow-up of elderly patients with locoregional breast cancer treated with tamoxifen only. British Journal of Surgery 78 213-217.

Howell A, DeFriend D, Robertson J, Blamey R \& Walton P 1995 Response to a specific antioestrogen (ICI 182780) in tamoxifenresistant breast cancer. Lancet 345 29-30.

Howell A, Robertson JF, Quaresma Albano J, Aschermannova A, Mauriac L, Kleeberg UR, Vergote I, Erikstein B, Webster A \& Morris C 2002 Fulvestrant, formerly ICI 182,780, is as effective as anastrozole in postmenopausal women with advanced breast cancer progressing after prior endocrine treatment. Journal of Clinical Oncology 20 3396-3403.

Jansen MP, Foekens JA, van Staveren IL, Dirkzwager-Kiel MM, Ritstier K, Look MP, Meijer-van Gelder ME, Sieuwerts AM, Portengen H, Dorssers LC et al. 2005 Molecular classification of tamoxifenresistant breast carcinomas by gene expression profiling. Journal of Clinical Oncology 23 732-740.

Jiang WG, Watkins G, Fodstad O, Douglas-Jones A, Mokbel K \& Mansel RE 2004 Differential expression of the CCN family members Cyr61, CTGF and Nov in human breast cancer. Endocrine-Related Cancer 11 781-791.

Johnston SR, Saccani-Jotti G, Smith IE, Salter J, Newby J, Coppen M, Ebbs SR \& Dowsett M 1995 Changes in estrogen receptor, progesterone receptor, and pS2 expression in tamoxifen-resistant human breast cancer. Cancer Research 55 3331-3338.

Kaplan E \& Meier P 1958 Nonparametric estimation from incomplete observations. Journal of the American Statistical Association 53 457-481.

Kilker RL, Hartl MW, Rutherford TM \& Planas-Silva MD 2004 Cyclin D1 expression is dependent on estrogen receptor function in tamoxifen-resistant breast cancer cells. Journal of Steroid Biochemistry and Molecular Biology 92 63-71.

Lo YL, Yu JC, Chen ST, Hsu GC, Mau YC, Yang SL, Wu PE \& Shen CY 2007 Breast cancer risk associated with genotypic polymorphism of the mitotic checkpoint genes: a multigenic study on cancer susceptibility. Carcinogenesis 28 1079-1086.

Lykkesfeldt AE, Madsen MW \& Briand P 1994 Altered expression of estrogen-regulated genes in a tamoxifen-resistant and ICI 164,384 and ICI 182,780 sensitive human breast cancer cell line, MCF-

7/TAMR-1. Cancer Research 54 1587-1595.
Lykkesfeldt AE, Larsen SS \& Briand P 1995 Human breast cancer cell lines resistant to pure anti-estrogens are sensitive to tamoxifen treatment. International Journal of Cancer 61 529-534.

Ma XJ, Wang Z, Ryan PD, Isakoff SJ, Barmettler A, Fuller A, Muir B, Mohapatra G, Salunga R, Tuggle JT et al. 2004 A two-gene expression ratio predicts clinical outcome in breast cancer patients treated with tamoxifen. Cancer Cell 5 607-616.

Martin LA, Pancholi S, Chan CM, Farmer I, Kimberley C, Dowsett M \& Johnston SR 2005 The anti-oestrogen ICI 182,780, but not tamoxifen, inhibits the growth of MCF-7 breast cancer cells refractory to long-term oestrogen deprivation through downregulation of oestrogen receptor and IGF signalling. EndocrineRelated Cancer 12 1017-1036.

Martinerie C, Gicquel C, Louvel A, Laurent M, Schofield PN \& Le Bouc Y 2001 Altered expression of novH is associated with human adrenocortical tumorigenesis. Journal of Clinical Endocrinology and Metabolism 86 3929-3940.

McCallum HM \& Lowther GW 1996 Long-term culture of primary breast cancer in defined medium. Breast Cancer Research and Treatment 39 247-259.

McClelland RA, Barrow D, Madden TA, Dutkowski CM, Pamment J, Knowlden JM, Gee JM \& Nicholson RI 2001 Enhanced epidermal growth factor receptor signaling in MCF7 breast cancer cells after long-term culture in the presence of the pure antiestrogen ICI 182,780 (Faslodex). Endocrinology 142 2776-2788.

McDonnell DP, Clemm DL, Hermann T, Goldman ME \& Pike JW 1995 Analysis of estrogen receptor function in vitro reveals three distinct classes of antiestrogens. Molecular Endocrinology 9 659-669.

Moy B \& Goss PE 2006 Estrogen receptor pathway: resistance to endocrine therapy and new therapeutic approaches. Clinical Cancer Research 12 4790-4793.

Naundorf H, Becker M, Lykkesfeldt AE, Elbe B, Neumann C, Buttner B \& Fichtner I 2000 Development and characterization of a tamoxifen-resistant breast carcinoma xenograft. British Journal of Cancer 82 1844-1850.

Niu Z, Ito M, Awakura Y, Takahashi T, Nakamura E, Ito N \& Ogawa O 2005 The expression of NOV and WT1 in renal cell carcinoma: a quantitative reverse transcriptase-polymerase chain reaction analysis. Journal of Urology 174 1460-1462.

Osborne CK 1998 Tamoxifen in the treatment of breast cancer. New England Journal of Medicine 339 1609-1618.

Osborne CK, Pippen J, Jones SE, Parker LM, Ellis M, Come S, Gertler SZ, May JT, Burton G, Dimery I et al. 2002 Double-blind, randomized trial comparing the efficacy and tolerability of fulvestrant versus anastrozole in postmenopausal women with advanced breast cancer progressing on prior endocrine therapy: results of a North American trial. Journal of Clinical Oncology 20 3386-3395.

Paik S, Shak S, Tang G, Kim C, Baker J, Cronin M, Baehner FL, Walker MG, Watson D, Park T et al. 2004 A multigene assay to predict recurrence of tamoxifen-treated, node-negative breast cancer. New England Journal of Medicine 351 2817-2826.

Parisot JP, Leeding KS, Hu XF, DeLuise M, Zalcberg JR \& Bach LA 1999 Induction of insulin-like growth factor binding protein expression by ICI 182,780 in a tamoxifen-resistant human breast cancer cell line. Breast Cancer Research and Treatment 55 231-242.

Perey L, Paridaens R, Hawle H, Zaman K, Nole F, Wildiers H, Fiche M, Dietrich D, Clement P, Koberle D et al. 2007 Clinical benefit of fulvestrant in postmenopausal women with advanced breast cancer and primary or acquired resistance to aromatase inhibitors: final results of phase II Swiss Group for Clinical Cancer Research Trial (SAKK 21/00). Annals of Oncology 18 64-69.

Peto R, Pike MC, Armitage P, Breslow NE, Cox DR, Howard SV, Mantel N, McPherson K, Peto J \& Smith PG 1977 Design and analysis of randomized clinical trials requiring prolonged observation of each patient. II. analysis and examples. British Journal of Cancer 35 1-39.

Scholz G, Martinerie C, Perbal B \& Hanafusa H 1996 Transcriptional down regulation of the nov proto-oncogene in fibroblasts transformed by p60v-src. Molecular and Cellular Biology 16 481-486. 
Shaw LE, Sadler AJ, Pugazhendhi D \& Darbre PD 2006 Changes in oestrogen receptor-alpha and -beta during progression to acquired resistance to tamoxifen and fulvestrant (Faslodex, ICI 182,780) in MCF7 human breast cancer cells. Journal of Steroid Biochemistry and Molecular Biology 99 19-32.

Speirs V, Parkes AT, Kerin MJ, Walton DS, Carleton PJ, Fox JN \& Atkin SL 1999 Coexpression of estrogen receptor alpha and beta: poor prognostic factors in human breast cancer? Cancer Research $\mathbf{5 9}$ 525-528.

Still IH, Hamilton M, Vince P, Wolfman A \& Cowell JK 1999 Cloning of TACC1, an embryonically expressed, potentially transforming coiled coil containing gene, from the 8 p11 breast cancer amplicon. Oncogene 18 4032-4038.

Tozlu S, Girault I, Vacher S, Vendrell J, Andrieu C, Spyratos F, Cohen P, Lidereau R \& Bieche I 2006 Identification of novel genes that co-cluster with estrogen receptor alpha in breast tumor biopsy specimens, using a large-scale real-time reverse transcription-PCR approach. Endocrine-Related Cancer 13 1109-1120.

Tzukerman MT, Esty A, Santiso-Mere D, Danielian P, Parker MG, Stein RB, Pike JW \& McDonnell DP 1994 Human estrogen receptor transactivational capacity is determined by both cellular and promoter context and mediated by two functionally distinct intramolecular regions. Molecular Endocrinology 8 21-30. van 't Veer LJ, Dai H, van de Vijver MJ, He YD, Hart AA, Mao M, Peterse HL, van der Kooy K, Marton MJ, Witteveen AT et al. 2002 Gene expression profiling predicts clinical outcome of breast cancer. Nature 415 530-536.

Vendrell JA, Magnino F, Danis E, Duchesne MJ, Pinloche S, Pons M, Birnbaum D, Nguyen C, Theillet C \& Cohen PA 2004 Estrogen regulation in human breast cancer cells of new downstream gene targets involved in estrogen metabolism, cell proliferation and cell transformation. Journal of Molecular Endocrinology 32 397-414.

Vendrell JA, Bieche I, Desmetz C, Badia E, Tozlu S, Nguyen C, Nicolas JC, Lidereau R \& Cohen PA 2005 Molecular changes associated with the agonist activity of hydroxy-tamoxifen and the hyper-response to estradiol in hydroxy-tamoxifen-resistant breast cancer cell lines. Endocrine-Related Cancer 12 75-92.

van de Vijver MJ, He YD, van't Veer LJ, Dai H, Hart AA, Voskuil DW, Schreiber GJ, Peterse JL, Roberts C, Marton MJ et al. 2002 A geneexpression signature as a predictor of survival in breast cancer. New England Journal of Medicine 347 1999-2009.

Wakeling AE, Dukes M \& Bowler J 1991 A potent specific pure antiestrogen with clinical potential. Cancer Research 51 3867-3873.

Received in final form 29 September 2008

Accepted 31 October 2008

Made available online as an Accepted Preprint 3 November 2008 